\title{
South-South migration and the labor market: Evidence from South Africa*
}

\author{
Costanza Biavaschi† Giovanni Facchini
}

August 2, 2017

\begin{abstract}
Using census data for 1996, 2001 and 2007 we study the labor market effect of immigration to South Africa. We exploit the variation - both at the district and at the national level in the share of foreign-born male workers across schooling and experience groups over time. In addition, we use an instrumental variable empirical strategy to estimate the causal effect of immigration on the local labor market. At the district level, we show that increased immigration has a negative and significant effect on natives' employment rates but not on total income. At the national level, we find that increased immigration has a negative and significant effect on natives' total income but not on employment rates. Our results are consistent with outflows of natives to other districts as a consequence of migration, as in Borjas (2006).
\end{abstract}

JEL classification numbers: F22, J61

Keywords: Immigration, Labor market effects, South Africa.

*The authors are most indebted to the Multi-Donor Trust Fund (MDTF) for generously funding the Grant: "Labor Markets, Job Creation, and Economic Growth: Migration and Labor Market Outcomes in Sending and Southern Receiving Countries" which made this paper possible. We would also like to thank Frederic Docquier, Caglar Ozden, Giovanni Peri and Hiller Rapoport and seminar audiences at Georgetown SFS-Q, the World Bank, the EIIT Conference at Purdue University, the IZA Annual Migration Meeting, the IZA-World Bank Conferences on Employment and Development in Cape Town and Mexico City, the Conference on Global Migration: Economics, Politics, Policy (Tulane University), the NORFACE Workshop in London, the CEPR PEGGED Conference in Turin on the "Economics and Politics of Immigration", and the PEGGED Conference in Brussels for providing useful comments.

$\dagger$ University of Reading and IZA; email: c.biavaschi@reading.ac.uk.

†The University of Nottingham, Universitá degli Studi di Milano, Centro Studi Luca d’Agliano, CEPR and CES-Ifo; email: giovanni.facchini@nottingham.ac.uk.

$\S$ Georgetown University, Centro Studi Luca d'Agliano, CEPR and IZA; email: amm223@georgetown.edu.

IUniversitá degli Studi di Milano Bicocca, Centro Studi Luca d'Agliano and IZA; email: mariapia.mendola@unimib.it. 
"...They come from all over, and they are of all sorts, the new African migrants. There are the professionals - the doctors and academics, highly educated and hoping that in this country their skills can at last earn them a living wage. There are the traders, buying up what the shopping malls have to offer, and traveling home twice a month with bulging suitcases... There are the hawkers and the hustlers, who travel south out of desperation... And then there are the criminals; the drug dealers, the pimps and fraudsters." (Phillips 2002)

\section{Introduction}

Recent evidence suggests that South-South migration is a sizeable phenomenon. For instance, Ratha and Shaw (2007) estimate that 74 million, or nearly half, of the migrants from developing countries live and work in other developing countries. In other words, South-South migration is almost as important as South-North migration. As a result, it is likely to have a substantial impact on the economies of these low and middle income destination countries. However, most likely due to data unavailability, there are almost no systematic studies of the impact of SouthSouth migration (Hatton and Williamson 2005). ${ }^{1}$ In this paper we contribute to this literature by analyzing the specific case of South Africa, which is an important destination of migrants in the developing world and, in particular, in Sub-Saharan Africa (Ratha and Shaw 2007). We first show that migration flows to South Africa are substantial and increasing, especially from neighboring African countries. Next, we analyze the impact of migrant flows on South Africans' labor market opportunities.

Following the demise of the Apartheid regime, important political changes have swept South Africa, leading to the 1994 election of a democratic government. At the same time, the country's position as a regional economic superpower has made it an attractive destination for migrant workers from surrounding areas in search of new employment opportunities. Until 2002, migration to South Africa was disciplined by the "Aliens Control Act" of 1991, a piece of legislation which was rooted in the "control and expulsion" mentality of the Apartheid era, inspired by a fundamentally racist perspective (Peberdy and Crush 1998). After 2002, with the introduction of the new Immigration Act (Act 13), and its subsequent amendment in 2004, the policy stance changed substantially. Today the South African government sees the inflow of foreign workers (and especially of skilled ones) as a tool for economic growth. This is a significant break from the control-oriented framework of the past.

Still, xenophobic episodes against immigrants are common place (McDonald 2000 and Friebel,

\footnotetext{
${ }^{1}$ One interesting exception is represented by Gindling's (2009) study of the effect of Nicaraguan migration to Costa Rica in the early years of this century.
} 
Gallego, and Mendola 2013) suggesting that natives often perceive immigrants as a threat. While several studies have provided a qualitative assessment of recent migration to South Africa, remarkably little systematic evidence exists on the labor market effect of foreign immigration to the country. The purpose of this paper is to shed light on this question and provide what is - to the best of our knowledge - the first systematic study of the labor market effect of immigration to this country. $^{2}$ In carrying out our analysis, we use three large datasets provided by Statistics South Africa covering 1996, 2001 and 2007.We start by documenting the patterns of immigration. First, we find that the number of foreigners has increased substantially over the period we are considering. In 1996, about 2.1 percent of the population (or 5.1 percent of the male labor force) was made up by migrants, and that share had grown to 2.7 percent of the population (or 6.1 percent of the male labor force) in 2007. Second, and contrary to beliefs widely held in the country, foreign male workers in South Africa are relatively highly educated. ${ }^{3}$ In particular, as of 2007, they are approximately four times more likely than native workers to have attained a college degree. The importance of foreign workers is even higher when we look at individuals at the very top of our skill classification, i.e. individuals who are not only highly educated, but also have a long labor market experience. Third, we find that other African countries are becoming an increasingly important source of immigrants to South Africa.

We next turn to the analysis of natives' labor market outcomes. We first follow an approach that exploits the variation in the distribution of immigrants of different skills across geographic sub-units within the country and over the three years of our sample. Our rich dataset allows us to identify 56 districts. We follow Borjas (2003) and define a skill level as being characterized by both educational achievement and labor market experience. We use an empirical specification that accounts for fixed effects along the three main dimensions of the analysis (skill, district and time) as well as all pairwise interaction terms. In these district-level regressions we find that immigration has, on average, no effect on natives' employment rates and income. One important caveat in interpreting the latter findings, though, is that the fixed effects estimates might suffer from an endogeneity bias. First, it is widely recognized that immigrants are not distributed randomly but instead tend to cluster in specific (e.g. economically stronger) locations. This reverse causality creates an upward bias in both employment-rates and total-income regressions. Alternatively, it might be that endogeneity arises because migration is itself caused by employed natives' outflows - due to better-paid labor market opportunities in other districts or abroad. In that case foreign

\footnotetext{
${ }^{2}$ See Crush and Williams (2010) and Landau and Segatti (2009) for a broad overview of the phenomenon, and McDonald (2000) for an insightful collection of essays looking at the evolution of migration in the early postApartheid era. Bhorat, Meyer, and Mlatsheni (2002) provides instead evidence on emigration of skilled workers from the Southern African region.

${ }^{3}$ In fact, as pointed out by Crush and Williams (2010), page 14, recent inflows of highly skilled workers from other African countries played an important role. In particular "The growing number and proportion of African immigrants suggest the beginning of a skills brain drain to South Africa, which could accelerate in the future."
} 
workers would be hired to fill up vacancies left open by natives in the South African labor market. This reverse causality creates a downward bias in the employment-rates regressions.

Thus, to obtain unbiased estimates and uncover causal effects, we implement an instrumental variable strategy. In particular, we follow Card (2001) and create a shift-share instrument which uses data on the distribution of immigrants across districts, by country of origin, during Apartheid (this data is from the 1991 South African Census). The instrument is based on evidence that networks are important determinants of migrants' location decisions (Munshi 2003). In addition, in the case of South Africa the exclusion restriction is likely to be satisfied for the following two reasons. First, black workers' movements were highly regulated by the government during Apartheid. Before 1994, black migrant workers were not free to choose, according to economic incentives, where to locate within South Africa. Historical evidence shows that the government's choice of locations where black migrants were allowed to live was in general driven by political/racial as opposed to economic determinants. Second, since the end of Apartheid implied a structural break in the economy of the country, the pattern of economic activity across districts changed substantially after 1994.Thus the pattern of migration in the Apartheid period is unlikely to be correlated with post-Apartheid economic conditions. The district-level IV estimates indicate a large and negative effect of immigration on natives' employment rates. Our preferred specification indicates that a ten percentage points increase in the share of migrants of a skill group in a given district leads to a 4.7 percentage points decrease in natives' employment rate. For example, the average percentage point increase - between 1996 and 2007 - in migration rates of university-educated migrants with more than 30 years of labor market experience, which is equal to approximately seven percentage points, implies a 3.2 percentage points decline in natives' employment rates. Thus, reverse causality and endogeneity appear to give rise to a bias towards zero in the fixed effects estimates of the employment-rates regressions. Finally, in the district-level IV regressions, we still find no effect of immigration on income.

Given the long history of ethnically/racially segmented labor markets in South Africa, and the substantial heterogeneity of immigration to South Africa both in terms of the migrants' ethnic background and skill level, we further investigate whether the IV findings are robust along these two dimensions. To this end we repeat our district-level analysis focusing, respectively, on three broad ethnic backgrounds and four separate education groups. We find that the negative causal impact of immigration on natives' employment persists across racial and skill groups.

There are several possible channels through which immigration may exert its causal impact on natives' employment rates at the district level. First, the impact of immigration on natives' employment rates may be direct, i.e. the arrival and hiring of immigrants may lead natives to lose their jobs. Alternatively, immigration may affect natives' employment rates indirectly. For example, immigration may have an impact on natives' formal labor-market participation (i.e., 
immigration may lead South African workers to move to the informal labor market which would amount to a decline in natives' formal employment rates). Another indirect channel is through the impact of immigration on natives' location within the country (i.e., immigration may induce natives' outflows to other districts and, to the extent that employed natives are more likely to leave than unemployed ones, this amounts to a decline in natives' employment rates in the district considered). Fourth, immigration could encourage native workers to leave South Africa and relocate abroad (i.e., immigration may give rise to emigration to other countries which would amount to a decline in natives' employment rates in South African districts - to the extent that employed natives are more likely to leave the country than unemployed ones). A priori all these mechanisms are consistent with our main findings.

To gain insights on which channels are at work, we carry out a national-level analysis à la Borjas (2003). We find, on average, no impact at the national level of immigration on natives' total employment rates and a negative and significant effect on total income. We also find heterogenous results for immigration across different types of workers (i.e. employees vs. self-employed): The impact of immigration on natives' self-employment rates - which was insignificant in the districtlevel OLS and IV regressions - is positive and significant in the national-level regressions. This findings can be interpreted in the light of the theoretical framework developed by Borjas (2006) to understand the link between the so called "spatial correlation" approach and "national level" studies of the impact of international migration. Building on the insight that natives react to the inflow of foreign workers in the local labor market where they reside by relocating to other regions of the country, he shows that the spatial correlation between native employment and the immigrant stock "...will be more negative when the model is estimated using geographically smaller labor markets, and that the spatial correlation between the wage and the immigrant stock will be more negative for larger labor markets." Our results thus provide evidence consistent with the adjustment mechanism studied by Borjas (2006) also in the context of a middle-income country, and are reinforced by the implementation of an instrumental variable strategy.

The remainder of the paper is organized as follows. Section 2 discusses the South African migration history, whereas section 3 introduces the data. Sections 4, 5 and 6 contain our empirical analysis, whereas section 7 concludes the paper.

\section{Migration to South Africa}

South Africa has been the destination of large cross border labor flows at least since the mid of the nineteenth century, when migrants from Lesotho, Malawi, Mozambique and Zimbabwe came to work in the sugar cane fields of Natal and the recently opened diamond mines in Kimberly (Crush 2000). 
In the last two decades of the Apartheid regime, growing racial tensions, coupled with a more active role played by labor unions in the domestic labor market, led the South African government to perceive black migration as a source of political threat. As a result, starting from the early seventies, black immigration - both legal and illegal - decreased substantially, thanks both to a reduction in the demand for foreign workers by domestic businesses and also to the stricter border enforcement policies, which were put in place by the government (Crush 2000). At the same time, up until the end of Apartheid, white immigrants have been welcome to the country, and policies have even been put in place to facilitate their arrival (for instance, free passage was offered to European immigrants during the sixties and seventies). Finally, the general stance towards refugees has been one of limited tolerance, especially in the case of the Mozambicans, who fled their country in large numbers following the civil conflict which saw South Africa as one of the main players.

In the post 1994 period, census data show that migration to South Africa has been characterized by a steady increase in the number of foreign residents in the country and by a change in the composition by source country. Interestingly, the flow of foreign workers has been remarkably less volatile than in other parts of the continent (Lucas 2006), even though in many cases it has remained temporary in nature. According to our data, over the period 1996-2007 the overall number of foreign born in South Africa has grown from approximately 830 thousand to 1.2 million, i.e. an increase of approximately 45 percent. As a result, in 1996 migrants represented 2.1 percent of the total population, whereas in 2007 they made up 2.7 percent of the total (see Figure 1). The importance of foreign workers is even greater. If we focus on males in the labor force (i.e. those who are either working or seeking work), the share of immigrants over the period grew from 5.1 percent in 1996 to 6.1 percent in 2007 (see Figure 2). Finally, note that these average figures hide substantial variation in the migration share across different locations within the country.

Table 1 uses information on country of birth of migrants, which was collected in the 1996 and 2001 censuses (unfortunately the same information is not available for 2007), to produce a picture of the evolution of the sources of South African migrants. What is immediately apparent is the growing importance of Africa. Between 1996 and 2001 the share of foreigners originating in the continent increased by 6.4 percentage points, from 64.6 to 71 percent of the total, with Mozambique and Zimbabwe being the main origin countries. Similar patterns can be observed also when we restrict our attention to males in the labor force: by 2001 almost four out of five migrant males in the labor force were born in other African countries.

The second element which emerges from Table 1 is the decline in the importance of Europe as a source. In 1996, individuals born in the European continent represented approximately 26 percent of the total migrants, whereas by 2001 that share had declined to 22 percent. Looking at the male labor force, the importance of European migrants declines even more, and by 2001 they 
represented only $15.9 \%$ of foreign male workers. Interestingly, there has been a significant decline in the relative importance of the UK as a source country.

This trend has resulted in important changes in the racial composition of the immigrant population relative to the native one. As shown in Table 2, in 199683.9 percent of the working age natives in the labor force were Blacks or Coloured, 12.4 percent were Whites, and only 2.9 percent Asians. Whites were substantially over-represented among immigrants, making up approximately 38 percent of the total. Blacks or Coloured were clearly under-represented at 58.8 percent of the total, whereas the share of Asians were remarkably low, at only 2.0. In 2007, in the presence of an essentially stable racial composition of the native population, the share of whites in the immigrant population declined substantially, to approximately 26.3 percent of the total - a reduction of 12.1 percentage points - whereas the share of Blacks or Coloured people increased to 69.4 percent an increase of 10.6 percentage points. The share of Asians among migrants also saw a steep rise, more than doubling to 4.3 percent of the total.

It is not clear how much of the evolution of South African migration by size, source country and racial composition is due to changes in migration policy. As has been argued by many observers, even in the aftermath of Apartheid's demise, the South African migration policy stance has continued to be rather restrictive (Peberdy 2001). In fact the 1991 Aliens Control Act, which has been nicknamed 'Apartheid's last act' (Landau and Segatti 2009), remained the cornerstone of South African immigration policy throughout the nineties. Drafted to simplify all the previous immigration laws enacted after 1937, the Aliens Control Act became increasingly controversial after the transition to the democratic regime, and was ultimately declared unconstitutional. Following this decision, a lengthy process was started to substantially reform the existing policy framework, which culminated in the Immigration Act of 2002 and in the subsequent Immigration Amendment Act of 2004. The two pieces of legislation are oriented towards favoring highly skilled immigration and investors. The initial quota allocation, as presented in February 2003, allowed for approximately 740,000 yearly permits. Since then, there has been a dramatic revision of the system and, in 2011, only 35,000 work permits were allocated through the quota system, covering 53 occupations (skills) deemed 'scarce and critical'.

This new policy led to a significant increase in the skill profile of immigrants to South Africa, and as pointed out by Crush and Williams (2010), "The growing number and proportion of African immigrants suggests the beginning of a skills brain drain to South Africa which could accelerate in the future." 


\section{Data}

For our main analysis we use three surveys carried out by the Statistical Office of the Republic of South Africa, which are available through the International IPUMS website. ${ }^{4}$ The 1996 and 2001 data are a ten percent sample from the population census and cover approximately 3.6 and 3.7 million individuals, respectively. ${ }^{5}$ The 2007 data are instead taken from the South African Community Survey, and cover approximately 2.2 percent of the population or 1.1 million individuals.

In collecting information for the South African Census and Community survey, an effort is made to cover also undocumented residents (i.e. illegal immigrants) (Statistics South Africa 2012), and in particular, no question is asked to elicit legal status. Existing estimates indicate that by the mid 90's the country harbored approximately 500,000 illegal immigrants (South African Department of Labour 2007 and Crush (1999)), and while it is likely that illegal immigrants will be underrepresented in our data, the undercount rates that can be obtained from the Census indicate that Statistics South Africa attempts to correct for this. ${ }^{6}$ Moreover, we address this concern in a series of robustness checks carried out in Section 5.

A wealth of information is collected in these data sets, including labor market outcomes and important individual-level characteristics. We restrict our analysis to men in the 16-65 age group, who participate in the civilian labor force (i.e., are not studying and are either working or seeking work). ${ }^{7}$ Furthermore, the large size of the samples allows us to fully exploit the spatial dimension of migration, taking advantage of the heterogeneity in the distribution of foreign workers across localities. In particular, we are able to use information at the district level (there are 56 districts in South Africa). An individual is defined to be an immigrant if he is foreign born.

As for measures of labor market outcomes, we have information on each individual's employment status (i.e., whether he is working or seeking work in the week when the census was carried out), type of employment (i.e., whether a person is self-employed or works for someone else) ${ }^{8}$ and total income. The latter is defined as the total personal income in local currency (Rand) from all

\footnotetext{
${ }^{4}$ See https://international.ipums.org/international/.

${ }^{5}$ The 1996 and 2001 census data undercount the total population by, respectively, 10.7 percent and 18 percent. Statistics South Africa and the IPUMS project provide a weight variable that is explicitly designed to adjust for the undercount. Naturally, we have used this weighting factor throughout our analysis. For more details about the data construction, see the working paper version of this article available from http://faculty.georgetown.edu/amm223/papers.htm.

${ }^{6}$ For example, considering different groups of origin countries, the implied undercount in the 1996 census was $8.78 \%$ for Asia, $8.93 \%$ for Europe, and $11.89 \%$ for the countries bordering South Africa, which are the most likely origins of illegal immigrants.

${ }^{7}$ One reason we exclude women from the sample is that there is more uncertainty for women on the time they enter and exit the labor market, thus our measure of labor-market experience would be very noisy.

${ }^{8}$ According to the classification adopted by Statistics South Africa, an "employee" is defined as a "person who works for someone else or a company for a wage or salary, or for commissions from sales or bonuses, or for payment in kind such as food, housing or training", whereas "self-employed" is a "person who has his or her own business or enterprise but does not employ other persons except for unpaid family workers".
} 
sources in the previous twelve months, and is reported in broad brackets. In all the three samples, the data on income are recoded to the midpoints of the broad intervals given in the original data, and suffer from the standard "top coding" problem, as the top interval is coded to its lowest possible value (e.g, code 360,001 for 360,001+). ${ }^{9}$ Unfortunately the data do not allow us to measure labor income separately from other sources of income, nor wages separately from the number of hours worked. Bearing in mind these limitations of our data, we have verified, using the Labor Force Survey (LFS), which in 2001 contains information on both monthly wages and total income, that the correlation between these two measures is positive and strongly significant for the total sample and also for the subsamples where the main earners are respectively employees and self employed individuals. ${ }^{10}$

One of the individual-level characteristics we consider to define the relevant unit of analysis is educational attainment, which is measured according to the following four categories: less than primary (the individual has completed less than 5 years of primary education), less than secondary (the individual has received between 5 and 11 years of education), secondary completed plus some college (the individual has at least 12 years of education, but has not completed college) and college completed (the individual has at least completed 16 years of education).We can compare the percentages of native and immigrant men, in the labor force, in each education category for the three years in our sample. Several interesting patterns emerge. First, the share of individuals who have not completed a primary education has fallen for both groups: for natives, from 27 percent in 1996 to 15.8 percent in 2007, whereas for immigrants the decline has been from 32.7 percent in 1996 to 21.1 percent in 2007. Second, highly skilled workers are becoming more common both among foreign born and natives. Among natives, between 1996 and 2007 the share of males in the labor force with a college degree has increased from 2.4 percent to 4.9 percent. Among the foreign born, the increase has been even more substantial: from 5.8 percent to 11.8 percent. In other words, in 2007 more than one out of ten foreign born males in the labor force had a college education, compared to one out of twenty natives. Interestingly, this pattern emerges while considering all groups of countries of origin (see Figure A1). Considering also the intermediate categories, the pattern that emerges from the data is one in which on average today's South African immigrants are at least as educated as their domestic counterparts, and their presence is particularly strong

\footnotetext{
${ }^{9}$ More precisely, in 1996 there are 14 brackets, starting at "No income" and reaching R 360,001+. For 2001 and 2007 information is instead reported using 12 brackets, starting again at "No income" and reaching R 2,457,601+. See Appendix Table A1 for more details.

${ }^{10}$ We cannot use the LFS for our baseline analysis because it does not contain information on the country of birth of the respondent. We have also investigated the relationship between total income and wages exploiting the variation at the province/skill level. In particular, we have used the 2001 and 2007 rounds of the LFS to construct a measure of average annual salary at the province/skill level. We have merged the latter variable with a measure of total income at the same level of aggregation constructed from the IPUMS data. Regression results show that salary and total income are strongly and significantly correlated also at the province/skill level. This evidence suggests that total income is likely to be a good proxy for the behavior of wages in South Africa. See Tables A2-A4 in the Appendix.
} 
at the very top of the educational attainment scale (see Table A5).

As has been forcefully argued by Borjas (2003) and Borjas (2006), skills are acquired both before and after an individual enters the labor market and, as a result, workers who have the same level of education, but different levels of experience, are imperfect substitutes in production. ${ }^{11}$ For this reason, to be able to assess the impact of foreign workers on natives' labor market opportunities, we need to take into account not only the formal schooling received by them, but also how long these workers have been active in the labor market.

To do this, we follow Borjas (2003) and define a skill group in terms of both schooling and labor market experience. The latter is identified as the number of years that have elapsed since the individual has completed school. We assume that the age of entry into the labor force is 16 for a worker in the "less than primary completed" category and 17 for a worker in the "less than secondary completed" category. We assume instead that the typical individual with a high school education or some college enters the labor force at 21 , whereas the typical college graduate enters the labor force at 23. ${ }^{12}$ Our measure is necessarily rough, though, as individuals might take for instance longer than the statutory number of years (we use four) to complete a college education or might decide not to immediately enter the labor market. Furthermore, this measure is particularly problematic for immigrants as it does not distinguish between experience which has been acquired working in the destination country and experience which has been acquired elsewhere.

To carry out our analysis, we assume that the maximum number of years of labor market experience is 40, and we follow the literature and create broad categories of labor market experience, based on five-year intervals. ${ }^{13}$ Table 3 report summary statistics on the share of immigrants in each skill category. What is immediately apparent is that in all the three years in our sample, immigrants are over-represented at the very top of the skill distribution. For instance, while in 1996 only 5.86 per cent of the immigrants have less than primary education and 1-5 years of experience, in the same year as many as 14.78\% have a college degree and 31-40 years of experience. These numbers also highlight that immigrants are more likely than natives to be at the top of the skill distribution. For instance, in 1996, an immigrant is 3.2 times as likely as a native to have a college degree and 31-40 years of labor market experience. In 2007, this likelihood has further increased to 4.1 times. ${ }^{14}$ Immigrants are only slightly more likely than natives to be at the bottom of the skill

\footnotetext{
${ }^{11}$ See also Ottaviano and Peri (2012) for an even finer distinction.

${ }^{12}$ This definition reflects the assumption that individuals enter the South African labor force at the legal working age of 15 years old and there is possibly a one year lag between the end of school and the entry into the labor force.

${ }^{13}$ The last category includes individuals with 31 to 40 years of labor market experience. This choice is driven by the low life expectancy in South Africa (56 years) compared to developed countries and enables us to have a large enough sample in all cells. Borjas (2006) has showed that using alternative intervals to define experience does not qualitatively affect the results.

${ }^{14}$ These numbers are calculated as the share of migrants in each cell (shown in Table 3 ) divided by the share of immigrants in the population, times the share of natives in the population divided by the share of natives in the cell. For instance, in 2007 that is 0.2113/0.061 times (1-0.061)/ (1-0.2113).
} 
distribution, i.e. not to have completed a primary education and have very limited labor market experience. These results reinforce our initial findings that today's educated immigrants are an important component of South Africa's foreign workers population, and that immigrants play a particularly important role in the supply of very high skills.

Our empirical analysis will exploit differential time variation in immigration across districts. ${ }^{15}$ For example, the City of Johannesburg metropolitan municipality in Gauteng has seen the number of foreign born male workers almost treble between 1996 and 2007 from 53 thousand to 134 thousand and, as of 2007, immigrants made up $12.8 \%$ of the total. The immigration dynamic in the Lejweleputsa district in the Free State has been instead more volatile, mirroring the fortunes and the demand for foreign workers of the dominant mining sector. In 1996 there were almost 40 thousand male foreign born workers in the province, representing about $20 \%$ of the total. The number had decreased to approximately 11 thousand in 2001, whereas by 2007 it had edged back to approximately 20 thousand, or $14.2 \%$ of the total. Finally, the Ehlanzeni district in Mpumalanga, at the border with Mozambique's Limpopo province, has seen its immigrant population peak in 2001 at approximately 24 thousand (14\% of the total), whereas by 2007 it had declined to 19 thousand or $10.7 \%$ of the total.

We will exploit this rich variation in the data to carry out our empirical analysis. Our main measure of immigration in local labor markets is given by $p_{i j t}$, i.e. the share of foreign born in the male labor force of a particular skill group $i$ in district $j$ at time $t$, which is defined as:

$$
p_{i j t}=M_{i j t} /\left(M_{i j t}+N_{i j t}\right)
$$

where $M_{i j t}$ is the number of male foreign born workers in skill group $i$ in district $j$ at time $t$ and $N_{i j t}$ represents the corresponding number of natives.

We can examine the general patterns in the data in Figure 3, which presents two scatter plots linking the inter-censual change in the immigrant share and the changes in native individuals' employment rateand (log) income. Both pictures suggest that natives' labor market outcomes in a given cell (defined as a skill profile in a given district) are uncorrelated with changes in the immigrant share in that cell. However, the figures do not control for important observable and non-observable characteristics. We will do so in the analysis carried out in the next section.

\footnotetext{
${ }^{15}$ As administrative boundaries have changed over the sample period included in our study, we have put special care to insure that the geographic area included in each district is kept constant over time by using information collected for finer geographical partitions.
} 


\section{Empirical specification}

In the first part of our empirical analysis, we assess the labor market effect of immigration in South Africa exploiting the variation in the distribution of foreign workers - of different skill levels - across local labor markets within South Africa and over time. Following the literature (Borjas 2006), we estimate the following specification:

$$
L_{i j t}=s_{i}+r_{j}+q_{t}+\left(s_{i} * r_{j}\right)+\left(s_{i} * q_{t}\right)+\left(q_{t} * r_{j}\right)+\beta_{p} p_{i j t}+\varepsilon_{i j t}
$$

where the dependent variable $L_{i j t}$ is a labor market outcome for male native workers in skill group $i$ (28 education by experience groups), district $j$ (56 districts), and Census year $t$ (3 years); $p_{i j t}$ is the main variable of interest. Controls include a vector of fixed effects $s_{i}$, indicating the skill level; a vector of fixed effects $r_{j}$ indicating the district of residence, and a vector of fixed effects $q_{t}$ indicating the time of the observation. These fixed effects control for differences in labor market outcomes across skill groups, local labor markets and over time. The interaction terms $s_{i} * q_{t}$ and $q_{t} * r_{j}$ control, respectively, for changes in the labor market outcomes of each skill group and of each district over the period we are considering in our sample, i.e. 1996-2007. The interaction $s_{i} * r_{j}$ indicates instead that we are identifying the coefficient of interest, $\beta_{p}$, from changes in natives' labor market outcomes and immigration rates that occur over time within a district/skill cell.

We carry out two sets of regressions, focusing on men in the working age group (16-65) in the labor force. The first examines the effect of immigration on native workers' employment rate. The second considers instead the effect of immigration on native workers' total income. In all our specifications, standard errors are clustered at the skill-district level.

The results are reported in Table 4, where we consider three different measures of natives' employment: the total employment rate, ${ }^{16}$ the share of employees in the labor force and the share of self employed in the labor force. We find that immigration has no significant impact on natives' total employment rate, and both on the share of employees and self employed in the labor force. For instance, in column 1 we present the estimate of the impact of immigration on natives' total employment rate. The estimated coefficient $\beta_{p}$ is 0.02 , with a standard error of 0.043 , i.e. statistically insignificant at all conventional levels and economically small. In columns (2) and (3) we look instead at the share of employees and self-employed in the labor force. We do so in order to explore whether the labor market impact of immigration is heterogenous across types of employment that entail a different degree of formality. In particular, according to the survey definition of self-employment, we use the latter as a proxy for informal employment. ${ }^{17}$ The results

\footnotetext{
${ }^{16}$ Defined as the sum of employees and self employed in the labor force.

${ }^{17}$ In the survey, a self-employed individual is defined as a person who "works for him/herself without employing anyone else". While not all self-employed, especially in developed countries, are likely to work in the informal sector, existing evidence suggests that rates of tax and social security evasion among the self-employed in developing or
} 
suggest that there is no effect of immigration on the total employment rate, and across different types of employment.

In columns (4) to (7) we turn to consider the effect of immigration on natives' income levels. Measurement error is likely to be a concern, given how income is reported in our data and as a result, our estimates should be taken with due caution. ${ }^{18}$ Furthermore, as we pointed before, our data only provides information on individuals' total personal income from all sources. As a result, it is not possible for us to disentangle changes in labor earnings from changes in other sources of income and, within labor earnings, changes in wages from changes in the number of hours worked. ${ }^{19}$ We start by examining the impact on the total income earned by male workers in the labor force (column 4), whereas in columns 5-7 we consider different subgroups of employed natives, i.e. all those in employment (column 5), the employees (column 6), and the self-employed (column 7). As can be seen from columns 4 and 5, the effect of immigration on the total income of individuals in the labor force and on employed individuals is not significant. The same holds true when we only consider the employees in column 6 and the self employed in column 7 .

Summarizing, our fixed effect estimations highlight that immigration has no effect on natives' employment rate and total income.

\section{$5 \quad$ IV results}

So far our results have highlighted the absence of a correlation, at the district-skill-year level, between the share of immigrants in the male labor force and natives' employment rate. To establish whether this relationship is causal, we employ an instrumental-variable methodology based on Card (2001).

It is well known that immigrants tend to settle in geographic areas where earlier migrants from the same origin country have established themselves (Bartel 1989). Assume that the total number of immigrants in South Africa from a given origin country is independent from the labor-demand conditions prevailing in any particular district of the country. Then we can decompose the actual inflow of immigrants from a given source country to a given district into an exogenous supply component - based on the total number of immigrants in South Africa from the given source country and the share of earlier immigrants from that country that live in that district - and a

middle-income countries are much higher than for employees (e.g. ILO 2002).

${ }^{18}$ The number of observations across specifications changes when we consider the effect of migration on income. There are two possible reasons for that. First, we might be simply missing information for income; second, the entire cell might be missing, for example because in a given magisterial district there are no native individuals who have achieved a certain level of education and a certain number of years of labor market experience. In the latter case, while the employment rate is zero, income is not defined. Thus, while we retain the information in the employment regressions, we drop this observation in the specifications with income.

${ }^{19}$ Notice though that total income and wages are highly correlated in South Africa both at the household level, and across skills/districts. See footnote 17 and results in Tables A2-A4. 
residual component - that reflects short term fluctuations from the long term patterns. Card's shift-share instrument is based on the idea that the exogenous supply component represents the supply shifter that can be used as an instrumental variable. More precisely, let $M_{o t}{ }^{20}$ be the number of immigrants from source country $o$ that are in South Africa at time $t$. Furthermore, let $\lambda_{o j}$ be the share of immigrants from country $o$ who were observed living in district $j$ in a previous period. Finally, let $\tau_{\text {oit }}$ be the fraction of immigrants from origin country $o$ that in year $t$ belong to skill group $i$. Our shift-share instrument is then defined as

$$
S S_{i j t}=\sum_{o} M_{o t} \lambda_{o j} \tau_{o i t}
$$

To construct $\lambda_{o j}$ we use information from the last population count conducted during the Apartheid period, i.e. the 1991 Census. This data set is available from Statistics South Africa. ${ }^{21}$ Given the changes that have taken place in the administrative subdivision of the country after the end of the Apartheid regime, we have devoted considerable effort to insure that the definition of our geographic unit of reference is stable over time.

The validity of the exclusion restriction of our IV is based on the assumption that the pattern of migration across districts in the Apartheid period (captured by the distribution of $\lambda_{o j}$ ) is not correlated with post-Apartheid economic conditions. Two points seem to suggest that this is the case. First, it is important to remember that, during the Apartheid period, the Group Areas Act of 1950 zoned the country into "white only" areas and "black" areas, and led to the forced relocation of about 3.5 million individuals, mostly blacks, colored or asians, who happened to be living in the "wrong" part of the country (Ross 2008). At the time, this represented approximately 10 percent of the total population, which often ended up carted off from city suburbs to the adjacent Bantustans that had been recently established. Subsequent pieces of legislation ${ }^{22}$ also

\footnotetext{
${ }^{20}$ Depending on data availability, the literature has considered both the effect of recent immigrant arrivals on changes in native's outcomes in models including fixed effects (e.g. changes in native employment/wages in Card (2001), prices in Cortes (2008) etc.) and the effect of immigrant stocks on native outcome levels (e.g. Mitaritonna, Orefice, and Peri (2017), Barone, D'Ignazio, De Blasio, and Naticchioni (2016), Giuntella and Mazzonna (2015)). Correspondingly the instruments have been constructed using national level recent immigrant arrivals or stocks. In the case of South Africa, we do not have information on immigrant recent arrivals. Note also that, following Cortes and Pan (2013) - to address the possible concern that the total number of immigrants (from a given source) may be correlated with local conditions at the district level - we have also replicated our analysis by omitting the contribution of district $j$ to the the total number of immigrants from a given source in each time period when constructing the instrument for that district. The results are unaffected.

${ }^{21}$ See http://interactive.statssa.gov.za:8282/webview/. The 1991 Census covered the main territory of the Republic of South Africa, while the "homelands" of Transkei, Bophuthatswana, Venda and Ciskei have been surveyed separately. The dataset we have used for the construction of our instrument is the result of the merger of the main data covering South Africa with the files for Bophuthatswana, Venda and Ciskei. Since Statistics South Africa does not make the data file for the Transkei available, we imputed data for this district.

${ }^{22}$ In particular the "Abolition of Passes and Consolidation of Documents Act" and the "Native Laws Amendment Act" of 1952. See also footnote 25 for more details.
} 
severely limited the ability of non-whites to relocate from the rural areas to the cities to look for employment, and these measures continued to be enforced until the very end of the Apartheid period. Thus, under the Apartheid regime, (black) migrant workers were not free to choose, according to economic incentives, where to locate within South Africa. Historical evidence also shows that the government's choice of locations where non-whites were allowed to live was in general driven by political/racial as opposed to economic determinants. Second, the end of Apartheid marked a sharp discontinuity not only in terms of social institutions, but also in terms of the performance of the South African economy. ${ }^{23}$ As argued by Du Plessis and Smit (2009), in the decade before the end of the Apartheid regime (1985-1994) per capita GDP in South Africa shrank at an annual rate of 1.3 percent, whereas in the decade that followed the end of Apartheid (19952004) it grew at an annual rate of 1.1 percent. Furthermore, real GDP per capita shrank by over 3.5 percent in 1991, while it grew by about 2 percent in 1996. In their analysis of the geographic distribution of economic activities in the post-1994 period, Bosker and Krugell (2008) emphasize the presence of a "heavily diverging regional income distribution..." (page 517) in South Africa in that period. Thus, the evidence from the literature seems to suggest that the end of Apartheid implied a structural break in the economy of the country and that the pattern of economic activity across districts changed substantially after 1994. Finally, to further assess the validity of our exclusion restriction, we have also directly used the information available in the Census data, looking at the male employment rate in 1991, 1996 and 2001 at the district level. We find evidence of little correlation over time. More specifically, running a simple linear regression we find that the correlation between employment in, respectively, 1991 and 1996 (or, between employment in 1991 and 2001) equals 0.003 (0.000) and is not statistically significant. All this evidence makes us confident that the distribution of migrants in South Africa's districts in 1991 is not correlated with the economic conditions prevailing in those districts in 1996 or 2001.

We extend the analysis of Table 4 by implementing the IV strategy. Note that the construction of both $M_{o t}$ and $\tau_{o i t}$ requires information on the country of origin of the immigrant, which in our data is only available for 1996 and 2001. This forced us to restrict our IV analysis to only these two years. ${ }^{24}$ The first column of Table 5 presents the first-stage regression and shows that the shift-share instrument is a strongly significant predictor of the distribution of immigrants across South African districts in 1996 and 2001. The F-statistic is 24 and suggests that the instrument is strong. Regressions (1) through (3) of Table 5 report the second-stage results for the effect of immigration on natives' employment rates, whereas columns (4) to (7) contain the findings for

\footnotetext{
${ }^{23}$ See for instance the essays in Aron, Kahn, and Kingdon (2009).

${ }^{24}$ We first replicated the fixed effects estimates but using only the two years of data, i.e. 1996 and 2001. We did so to have a benchmark for the IV estimates. We could see that the sign, significance levels and actual magnitudes of the estimated impact of immigration on native employment and income, respectively, were hardly affected when we focus on only two years of data, rather than on the full sample. Results are available upon request.
} 
income.

We find that immigration has a negative and significant impact on natives' total employment rate and that this effect is driven by the impact on the share of employees, whereas the effect on the share of self-employed is not significant. As for the impact on total employment, our results in column (1) indicate that an increase by 10 percentage points in the labor supply of a skill group, brought about by immigration in a given district, leads to a 4.7 percentage points decrease in natives' employment rate. For example, the average percentage point increase - between 1996 and 2007 - in migration rates of university-educated migrants with 31-40 years of labor market experience, which is equal to approximately seven percentage points, implies a 3.2 percentage points decline in natives' employment rate. Overall, the IV estimates for the impact of immigration on employment rates are larger in absolute value than the fixed effect ones (compare regressions in Table 5 to regressions in Table 4), suggesting that the fixed-effects estimates are biased towards zero. The direction of the bias is therefore consistent with the idea that immigrants cluster in economically stronger locations. In columns (4) to (7) we run the analysis for income. The results confirm what we have already identified in the fixed effect estimations: there is no statistically significant effect of immigration on income.

Before discussing the possible mechanisms behind the IV result, we further explore the impact of immigration on native employment by considering subsamples of the data built along two important dimensions. This allows us to examine weather there are heterogenous effects of immigration on natives across different groups and to highlight the robustness of our findings in Table 5.

First, we investigate whether immigration had a different impact on different racial groups of natives. Ethnicity and race have played an important role in South African history and, in particular, in the functioning of the country's labor market, at least since the introduction in the early fifties of measures that formally limited the ability of non-white citizens to move freely across the country in search for employment. ${ }^{25}$ The fall of Apartheid and the subsequent introduction of affirmative action measures - contained in the Black Economic Empowerment (BEE) Laws promoted by the Mandela government - completely changed the opportunities of the different racial groups within the labor market. In addition, the racial composition in South Africa has been affected by immigration since immigrants and natives differ substantially from a racial point of view. In particular, the growing attractiveness of post Apartheid South Africa as a destination for South-South migrants has led to a substantial decline in the relative importance of whites among the foreign born. For all these reasons we focus our analysis on different racial groups

\footnotetext{
${ }^{25}$ The two most important measures are the cynically entitled "Abolition of Passes and Consolidation of Documents Act" of 1952 and the "Native Laws Amendment Act" of the same year. To enjoy the right of permanent residence in a city - the notorious Section 10 right - a man had to have been born in the town or have worked continuously for the same employer for the past ten years, or for different employers for the past fifteen years. Those who violated this measure could be "endorsed out" of the urban area to the reserves which had been designated for them by court order. See Ross (2008).
} 
of natives. Second, since the skill distribution of immigrants differs substantially from that of natives (see section 3), it is interesting to study whether the labor market effects of immigration are heterogeneous across different skill groups.

We start by investigating whether the impact of immigration varies when we focus on different racial groups. We classify native born workers to be White, Black/Coloured or Asian. ${ }^{26}$ Our results are reported in Tables 6 . The specifications in this table use the same observations as in our main regressions except for the fact that the value of the dependent variable is different, since it now captures race-specific employment rates or income for natives. ${ }^{27}$ In particular, in the first panel of Table 6 we look at the effect of immigration on race-specific employment rates, whereas in the second panel of Table 6 we focus on race-specific total income. Our findings in Table 6 suggest that immigration has a negative effect on Whites and Blacks/Coloured employment rates, whereas there is no effect on the Asian subgroup. However, for the Asian subsample we cannot draw strong conclusions since the F-statistic of that regression is very low (6.956). ${ }^{28}$ The results in the second panel confirm that, at the district level, immigration does not have a significant effect on natives' incomes for any of the South African racial groups.

Last, we investigate the role of immigration on different skill groups of natives. In Table 7, we use the same observations as in columns (1)-(3) of Table 5, but we consider four subsamples, corresponding to each of the four education levels. In column 1 we focus on natives with less than primary education completed, whereas in columns 2-4 we look at those who have completed, respectively, less than a secondary education, a secondary education plus some college or a university degree and above. The pattern that emerges from the Table is that the average effect of immigration on the employment rate of natives is driven by unskilled and skilled workers, on which immigrants have statistically similar effects. On the other subgroups the effect is insignificant, although for individuals with less than secondary education completed we cannot draw strong conclusions since the F-statistic of that regression is very low (2.480). ${ }^{29}$ In the second panel of Table 7 we explore whether there is instead a heterogeneous effect of immigration on the total income of natives of different education levels. As for all our results, we do not find a significant impact of immigration on natives' total income levels, no matter what educational segment of the

\footnotetext{
${ }^{26}$ This ethnic classification, based on race, is inherited from the Apartheid era and has been retained by the South African Statistical Office for historical comparison purposes. Yet, the reader should be aware that South Africa is a setting with a more complex social cleavage structure that goes beyond racial traits.

${ }^{27}$ Compared to our main regressions, the number of observations is now lower because not in all skill/district cells we observe all the different racial groups. Skill/district cells in which a specific group does not exist will not enter our sample.

${ }^{28}$ Note though that the three coefficients are not statistically different from each other. In particular, a t-test for difference in coefficients between the White and Black/Coloured subsamples gives a p-value $=0.314$; a t-test for difference in coefficients between the White and the Asian subsamples gives a p-value $=0.231$; a t-test for difference in coefficients between the Black/Coloured and the Asian subsamples gives a p-value $=0.382$.

${ }^{29}$ In particular, a t-test for difference in coefficients in the less than primary and college education gives a p-value $=0.297$.
} 
labor market we consider.

Before concluding, we have taken a series of steps to address the potential undercount of illegal migrants, which for a developing country like South Africa, might be a concern. First, the estimates obtained above while focusing on skilled migration are especially comforting since they show that a negative and significant effect of migration takes place in a sample where illegal migration, and thus measurement error, is unlikely to be a concern. Second, to provide additional evidence that our results are not qualitatively affected by the potential undercount of illegal migrants, we run a specification which excludes from the sample all those districts at the border with Botswana, Mozambique, Namibia, Swaziland, Zimbabwe and Lesotho, which are more likely to be affected by the presence of illegal immigrants. Table ?? reports the results. Across all models, our findings are consistent with results reported in our benchmark specification of Table 5. Additionally, all the estimates are both statistically and economically similar to the benchmark analysis. While we cannot exclude that illegal immigration is present in our data, the evidence presented in Table ?? suggests that the undercount of illegal migrants is unlikely to affect our main conclusions. ${ }^{30}$

The main message that emerges from the IV analysis is that at the district level immigration has a negative and significant effect on natives' employment rates, whereas there is no impact of immigration on income. Moreover, the average negative effect on natives' employment rates is driven by a reduction in share of employees in total employment, whereas the share of selfemployed natives is not significantly affected by immigration. Additionally, these findings highlight similarities in the labor market adjustment process across different race and education groups.

\section{Estimates at the national-level}

The analysis we have carried out so far does not allow us to disentangle the channel through which natives react to the arrival of immigrants. First, the impact of immigration on natives' employment rates may be direct, i.e. the arrival and hiring of immigrants may lead natives to lose their jobs. A second possible mechanism is represented by the indirect effect of immigration on native workers' employment rate through their displacement from the formal to the informal labor market. A third possibility is represented by the indirect effect of immigration through the relocation of natives from high-immigration districts to low-immigration ones: To the extent that employed natives are more likely to leave than unemployed ones, natives' outflows reduce natives' employment rates. Another explanation would suggest instead that immigration causes native workers to leave South

\footnotetext{
${ }^{30}$ As pointed out by a referee, an additional source of concern is that young and low skilled immigrants might be undercounted in the South African census. To address this concern, we have run a series of robustness checks, in which we exclude from the sample those skill-district cells which are arguably more likely to be affected by measurement error. In particular, we dropped from the analysis very low skilled individuals, i.e. those with less than primary education and less than 5 years of experience. Our findings are qualitatively consistent with the benchmark results, and are available from upon request from the authors.
} 
Africa, and relocate abroad. A priori all these mechanisms are consistent with our main findings.

In order to shed light on the several possible channels, we use the theoretical framework recently developed by Borjas (2006) to link the local and national labor market effects of immigration. The goal of his analysis is to investigate whether the reaction of natives to the arrival of immigrants in a local labor market can explain the contrasting results which have been obtained in the literature, namely that the wage effect of immigration is very small or nil in most spatial correlation studies, whereas in several national-level analyses these effects have been found to be negative and significant. The main idea of the model is that, by depressing local wages, the arrival of immigrants in a particular labor market will induce an outflow of native workers to other labor markets, less affected by the phenomenon. In what follows we will summarize the main building blocs of Borjas' analysis, and refer the reader to the original paper for the details of the derivations.

Formally, consider a local labor market $j$, in which individuals characterized by a skill level $i$ operate at time $t$. Labor demand is given by a simple constant elasticity function with a factor price elasticity $\eta<0$. Let $N_{i j t}$ be the number of native workers active in that labor market at time $t$ and consider a scenario in which at each time period $t$, a cell $i j$ receives a migrant influx $M_{i j t}=M_{i j}$, which is assumed to continue to occur in every subsequent period $t$. Following the arrival of immigrants in a given labor market, the local wage will decline instantaneously, and differences in wages across local labor markets will lead to native internal migration. The native's reaction to factor price differences across local labor markets occurs with a one period delay, and the native labor supply elasticity is given by $\sigma>0 .{ }^{31}$ Solving the model, and in particular taking into account the dynamic response of employment and wages to the shocks, leads to the two key equations describing respectively the (log) stock of native workers employed in the cell and the corresponding (log) wage, i.e.:

$$
\begin{aligned}
\log N_{i j t} & =\log N_{i j,-1}+\left[(1+\eta \sigma)^{t+1}-1\right] \lambda_{i j} \\
& +\left[\frac{t}{t+1}+\frac{(1+\eta \sigma)}{\eta \sigma} \frac{1-(1+\eta \sigma)^{t}}{(t+1)}\right] \tilde{m}_{i t} \\
& -\left[\frac{t}{t+1}+\frac{(1+\eta \sigma)}{\eta \sigma} \frac{1-(1+\eta \sigma)^{t}}{(t+1)}\right] \tilde{m}_{i j t}
\end{aligned}
$$

where $\lambda_{i j}=\log \left(\frac{N_{i j,-1}}{N_{i}^{*}}\right), N_{i}^{*}$ is the number of native workers in skill group $i$ that would live in each region in the long run equilibrium, $\tilde{m}_{i t}=(t+1) m_{i}, \tilde{m}_{i j t}=(t+1) m_{i j}, m_{i j}=\frac{M_{i j}}{N_{i j,-1}}, m_{i}=\frac{M_{i}}{N_{i,-1}}$ and

$$
\begin{aligned}
\log w_{i j t} & =\log w_{i j,-1}+\eta\left[(1+\eta \sigma)^{t+1}-1\right] \lambda_{i j} \\
& +\eta\left[\frac{t}{t+1}+\frac{(1+\eta \sigma)}{\eta \sigma} \frac{1-(1+\eta \sigma)^{t}}{(t+1)}\right] \tilde{m}_{i t}
\end{aligned}
$$

\footnotetext{
${ }^{31}$ See Borjas (2006) for additional details.
} 


$$
+\eta\left[\frac{1}{t+1}+\frac{(1+\eta \sigma)}{\eta \sigma} \frac{1-(1+\eta \sigma)^{t}}{(t+1)}\right] \tilde{m}_{i j t}
$$

The first two terms in each equation highlight the role of the initial conditions. The following two lines show how native employment and wages adjust to the presence of immigrants. Consider the impact of the region specific shock $m_{i j t}$. In the very long run $(t \rightarrow \infty)$ the coefficient in the native employment equation converges to -1 , whereas the coefficient in the wage equation converges to 0 . In other words, as time between the arrival of immigrants and the measurement of the variables increases, native migration behavior tends to completely neutralize the local supply shock brought about by immigration, and makes it less likely that the analysis based on spatial correlations will be able to detect any effect on wages.

After simplifying the expressions (see Borjas (2006) for details) equations 3 and 4 can be brought to the data as follows:

$$
\begin{aligned}
\log N_{i j t} & =\log N_{i j,-1}+\eta \sigma \lambda_{i j}+\eta \sigma\left(t \lambda_{i j}\right)-\eta \sigma \tilde{m}_{i t}+\eta \sigma \tilde{m}_{i j t} \\
\log w_{i j t} & =\log w_{i j,-1}+\eta^{2} \sigma \lambda_{i j}+\eta^{2} \sigma\left(t \lambda_{i j}\right)-\eta^{2} \sigma \tilde{m}_{i t}+\eta^{2} \sigma \tilde{m}_{i j t}
\end{aligned}
$$

Remember that $\eta<0$ and $\sigma>0$, and assume as in Borjas $(2006)$ that $0<(1+\eta \sigma)<1$. As a result, the spatial correlation (i.e. the coefficient on $\tilde{m}_{i j t}$ ) estimated in the native employment equation becomes more negative the higher is $\sigma$, whereas the spatial correlation in the wage equation becomes instead less negative the higher is $\sigma$. Furthermore, assume that the supply elasticity $\sigma$ is larger when migration is less costly, i.e. when the labor market is geographically small. It follows that the spatial correlation between native employment and the immigrant stock variable "will be more negative when the model is estimated using geographically smaller labor markets, and that the spatial correlation between the wage and immigrant stock variable will be more negative for larger labor markets." (Borjas (2006), page 229). This is the basic prediction we assess in our analysis.

To this end, we have replicated the fixed effect estimates focusing on the national labor market. Using three years, and retaining our definition of skill, we now have a total of 84 observations (3 $\mathrm{x}$ 28). The OLS national-level results on employment are reported in columns (1) to (3) of Table 8 , whereas those on income appear in columns (4) to (7) of the same table. Since the nationallevel estimates are not affected by the same source of endogeneity bias altering the district-level ones, we compare the national-level results with the IV estimates at the district-level. By looking at Table 5 and Table 8, we see that, while at the local level the impact of immigration on the native employment rate and on share of employees is significant, this is no longer the case at the national level. In addition, the estimated effect at the national level on the share of self employed natives is significant but positive, while it was insignificant at the local level. Looking at the 
effect of migration on income, we observe the opposite pattern: in our local level analysis, we did not uncover a significant impact of immigration on incomes, whereas at the national level we find a negative and significant effect (except for self-employed natives). While the former result could be due to measurement error, ${ }^{32}$ the patterns we observe when moving to the national level suggests that these findings are compatible with employed native workers reacting to the arrival of immigrants in their district by moving into self-employment and to different geographic areas less affected by the phenomenon, as predicted by Borjas' (2006) model.

Additionally, we can directly explore the impact of immigration on natives' outflows using as the dependent variable the (log) size of the native population in a given cell (see also Borjas 2006) - given that unfortunately we do not have information on previous location at the district level. We find evidence consistent with natives' outflows as a consequence of migration when we run both OLS and IV district-level regressions (see column (1) in Table 9). In columns (2) and (3) we investigate whether natives' outflows due to migration are larger for employed vs. unemployed individuals. We find that employed natives are more likely than unemployed ones to leave a highmigration district, which is consistent with natives' employment rates being reduced by migration. Thus our main results - negative local employment effects and large national wage effects - can be interpreted as being due to mostly employed natives leaving the cell. In other words, the local IV employment effects reflect selection, ${ }^{33}$ specifically the natives who move out are a selected sample of natives in the district. At the same time, the lack of an effect on the employment rate of natives at the national level suggests that employed natives who leave the district find a job in another district.

\section{Conclusions}

In this paper we carry out what is, to the best of our knowledge, the first systematic study of the labor market effect of immigration to South Africa in the post-Apartheid era. We start by documenting how immigration is becoming more and more important for the country and highlight that, as a share of the population, immigration has increased by about $45 \%$ over the period considered in our analysis. Next, we show that immigrants to South Africa are at least as educated as natives and that highly educated foreign individuals are especially important at the very top of the skill distribution.

We then study the labor market effect of immigration, looking at its impact on both natives' employment rates and incomes. Our fixed effects, district-level, OLS analysis suggests that neither the employment rates of natives nor income have been adversely affected by the arrival of foreign

\footnotetext{
${ }^{32}$ Remember that our income variable is measured in intervals.

${ }^{33} \mathrm{We}$ would like to thank one of the referees for suggesting this interpretation.
} 
workers. As migration is likely to be endogenous, we take advantage of a quasi-experimental setting brought about by the fall of the Apartheid regime to construct an instrument for migration rates and show that our OLS estimates are biased. In the IV estimates we find that migration has a negative and significant effect on employment rates - except on self-employment rates where the estimate is insignificant - and no effect of income. Given the unique history of South Africa, we also explore the effect of migration on different segments of the population, defined on the basis of both skill and race. Our findings suggest that the negative impact of immigration on natives' employment broadly persists across racial and skill groups.

To gain further insights on the various mechanisms through which natives react to immigrant inflows, we have complemented our district level analysis with an investigation at the national level. At the national level, we find on average no impact of immigration on natives' employment rates, and a negative and significant effect on total income. We also find heterogenous results for immigration across different types of workers (i.e. employees vs. self-employed). The impact of immigration on natives' self-employment rates is positive and significant in the national-level regressions. These results suggest that the observed reduction in natives' employment rates at the district level is likely to be the result of natives' outflows from high-immigration to low-immigration districts (as in Borjas 2006) and of the relocation of natives from the formal to the informal labor market. 


\section{Figures}

Figure 1: Stock of foreign born in the total population, 1996-2007

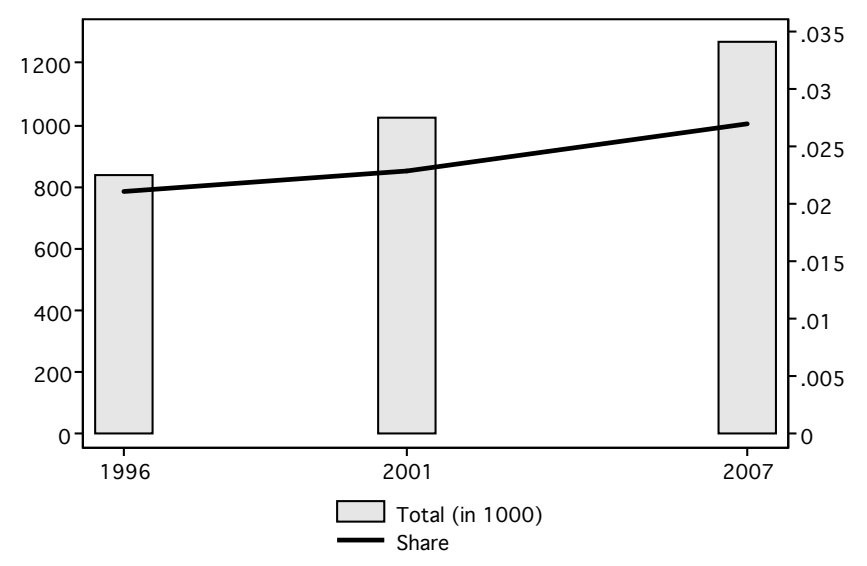

Figure 2: Stock of foreign born in the male labor force, 1996-2007

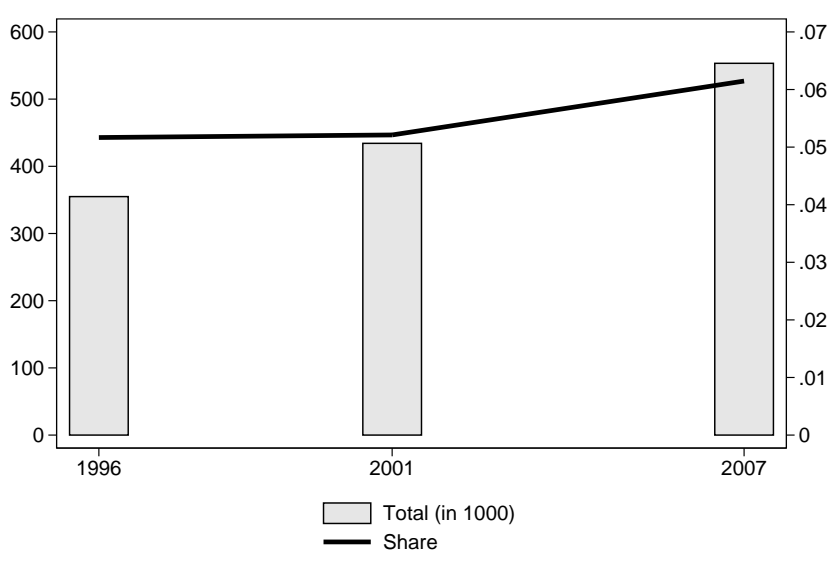


Figure 3: Scatter plots immigration and native's labor market outcomes

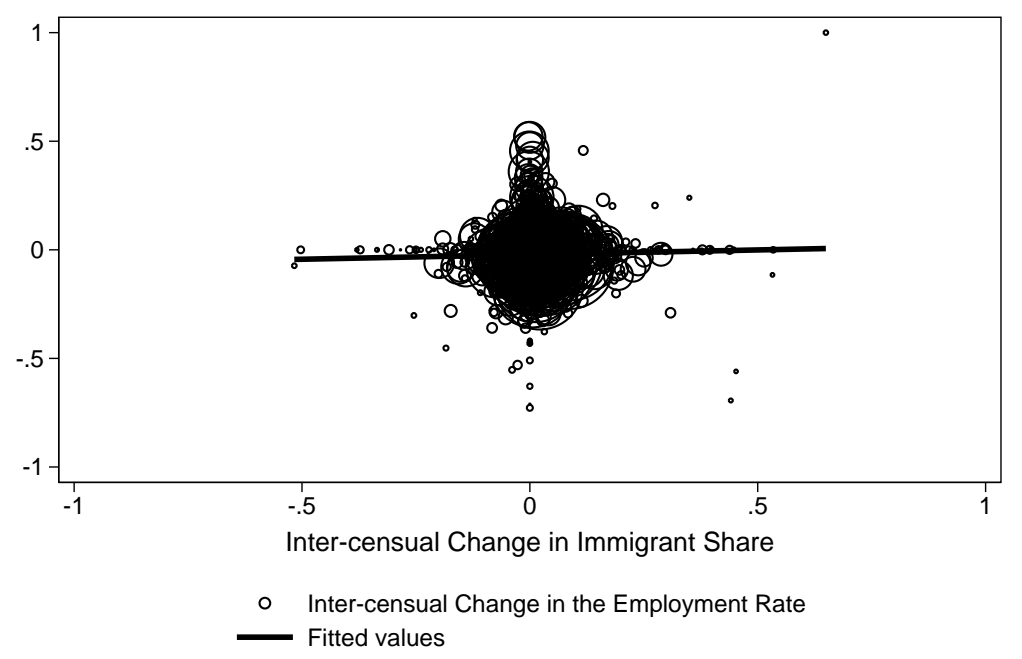

(a) Employment Rates

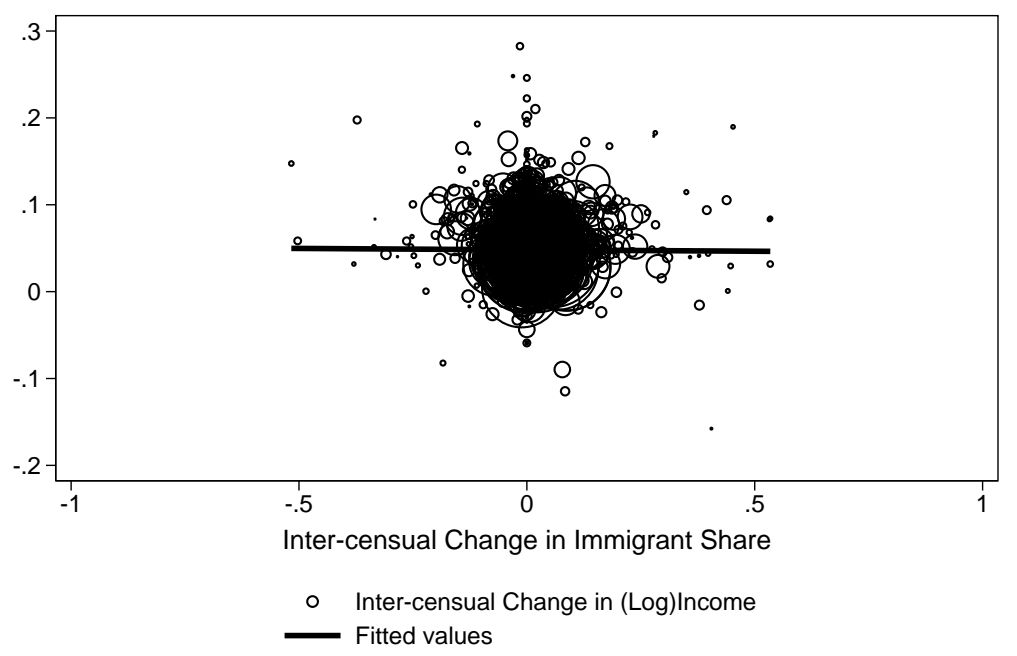

(b) Income (in logs) 


\section{Tables}

Table 1: Migrants by country of origin

\begin{tabular}{|c|c|c|c|c|c|c|c|c|}
\hline & \multicolumn{4}{|c|}{1996} & \multicolumn{4}{|c|}{2001} \\
\hline & \multicolumn{2}{|c|}{ All migrants } & \multicolumn{2}{|c|}{ Male labor force } & \multicolumn{2}{|c|}{ All migrants } & \multicolumn{2}{|c|}{ Male labor force } \\
\hline & Stock & Rates & Stock & Rates & Stock & Rates & Stock & Rates \\
\hline AFRICA & 541,028 & 0.646 & 267,188 & 0.753 & 728,143 & 0.710 & 344,351 & 0.794 \\
\hline Eastern Africa & 328,679 & 0.393 & 160,930 & 0.453 & 342,780 & 0.334 & 243,356 & 0.561 \\
\hline Malawi & 11,409 & 0.010 & 5,227 & 0.015 & 26,662 & 0.030 & 14,584 & 0.034 \\
\hline Mozambique & 206,707 & 0.250 & 112,695 & 0.318 & 269,872 & 0.260 & 155,156 & 0.357 \\
\hline Zambia & 15,540 & 0.020 & 5,229 & 0.015 & 23,985 & 0.020 & 7,745 & 0.018 \\
\hline Zimbabwe & 82,653 & 0.100 & 34,256 & 0.097 & 132,149 & 0.130 & 58,176 & 0.134 \\
\hline Middle Africa & 13,160 & 0.016 & 4,047 & 0.011 & 156,709 & 0.153 & 9,238 & 0.021 \\
\hline Nothern Africa & 2,116 & 0.003 & 628 & 0.002 & 4,015 & 0.004 & 1,409 & 0.003 \\
\hline Southern Africa & 185,137 & 0.221 & 96,762 & 0.273 & 179,781 & 0.175 & 83,244 & 0.192 \\
\hline Botswana & 11,897 & 0.010 & 6,951 & 0.020 & 18,022 & 0.020 & 6,245 & 0.014 \\
\hline Lesotho & 114,933 & 0.140 & 68,967 & 0.194 & 116,354 & 0.110 & 50,487 & 0.116 \\
\hline Namibia & 32,733 & 0.040 & 8,088 & 0.023 & 45,355 & 0.040 & 13,573 & 0.031 \\
\hline Swaziland & 25,574 & 0.030 & 12,756 & 0.036 & 32,524 & 0.030 & 12,940 & 0.030 \\
\hline Western Afrcia & 4,390 & 0.005 & 1,545 & 0.004 & 43,311 & 0.042 & 7,026 & 0.016 \\
\hline AMERICA & 14,730 & 0.018 & 4,097 & 0.012 & 12,568 & 0.012 & 5,182 & 0.012 \\
\hline ASIA & 29,083 & 0.035 & 8,435 & 0.024 & 48,496 & 0.047 & 15,152 & 0.035 \\
\hline EUROPE & 216,234 & 0.258 & 63,736 & 0.180 & 226,838 & 0.221 & 68,913 & 0.159 \\
\hline United Kingdom & 120,521 & 0.140 & 35,399 & 0.100 & 128,875 & 0.130 & 38,172 & 0.088 \\
\hline Germany & 19,103 & 0.020 & 5,322 & 0.015 & 24,408 & 0.020 & 6,221 & 0.014 \\
\hline Portugal & 14,488 & 0.020 & 5,678 & 0.016 & 19,513 & 0.020 & 7,372 & 0.017 \\
\hline OCEANIA & 4,257 & 0.005 & 1,208 & 0.003 & 4,531 & 0.004 & 4,435 & 0.001 \\
\hline NS/NR & 32,229 & 0.039 & 10,232 & 0.029 & o & 0.000 & 0 & 0.004 \\
\hline
\end{tabular}

Source: Census data, 1996 and 2001.

Male labor force includes only male migrants, 16-65 years old, in the labor force.

Rates are calculated as the number of immigrants from each specific country/region, over the total number of immigrants. 
Table 2: Ethnic Composition

\begin{tabular}{|c|c|c|c|c|c|c|c|c|c|c|c|c|}
\hline & \multicolumn{6}{|c|}{ Natives } & \multicolumn{6}{|c|}{ Migrants } \\
\hline & \multicolumn{2}{|c|}{ Total } & \multicolumn{2}{|c|}{ Men } & \multicolumn{2}{|c|}{ Women } & \multicolumn{2}{|c|}{ Total } & \multicolumn{2}{|c|}{ Men } & \multicolumn{2}{|c|}{ Women } \\
\hline & Stock & Rate & Stock & Rate & Stock & Rate & Stock & Rate & Stock & Rate & Stock & Rate \\
\hline & \multicolumn{12}{|c|}{1996} \\
\hline White & $1,733,793$ & 12.41 & 979,277 & 13.33 & 754,516 & 11.39 & 211,625 & 38.43 & 123,693 & 31.07 & 87,932 & 57.63 \\
\hline Black/Coloured & $11,716,448$ & 83.86 & $6,050,250$ & 82.37 & $5,666,199$ & 85.52 & 323,716 & 58.78 & 263,184 & 66.10 & 60,532 & 39.67 \\
\hline Asian & 412,073 & 2.95 & 258,710 & 3.52 & 153,363 & 2.31 & 10,836 & 1.97 & 7,885 & 1.98 & 2,951 & 1.93 \\
\hline \multirow[t]{2}{*}{ Unknown } & 108,568 & 0.78 & 56,677 & 0.77 & 51,891 & 0.78 & 4,555 & 0.83 & 3,394 & 0.85 & 1,161 & 0.76 \\
\hline & \multicolumn{12}{|c|}{2001} \\
\hline White & $1,798,264$ & 10.13 & 995,084 & 10.93 & 803,179 & 9.29 & 227,165 & 33.4 & 131,446 & 28.10 & 95,719 & 45.08 \\
\hline Black/Coloured & $15,478,997$ & 87.2 & $7,820,187$ & 85.89 & $7,658,811$ & 88.54 & 435,229 & 64.0 & 322,969 & 69.03 & 112,260 & 52.87 \\
\hline \multirow[t]{2}{*}{ Asian } & 477,451 & 2.69 & 289,201 & 3.18 & 188,250 & 2.18 & 17,758 & 2.61 & 13,424 & 2.87 & 4,333 & 2.04 \\
\hline & \multicolumn{12}{|c|}{2007} \\
\hline White & $1,884,617$ & 10.95 & $1,009,837$ & 11.56 & 803,179 & 10.31 & 216,293 & 26.29 & 122,794 & 21.6 & 93,499 & 36.63 \\
\hline Black/Coloured & $14,825,352$ & 86.1 & $7,429,389$ & 85.07 & $7,658,811$ & 87.17 & 570,686 & 69.38 & 416,536 & 73.4 & 154,151 & 60.39 \\
\hline Asian & 507,948 & 2.95 & 293,725 & 3.36 & 188,250 & 2.52 & 35,596 & 4.33 & 27,984 & 4.93 & 7,612 & 2.98 \\
\hline
\end{tabular}

Note: the reference sample for calculating rates is the weighted working age population (16-65) in the labor force.

Rates are calculated as the number of natives/immigrants by race, over the total number of natives/immigrants. 
Table 3: Migration share by education and experience (skill cell, 15-65 male lab force pop)

\begin{tabular}{|c|c|c|c|c|}
\hline Education & $\begin{array}{c}\text { Years of } \\
\text { experience }\end{array}$ & 1996 & 2001 & 2007 \\
\hline \multirow[t]{7}{*}{ Less than primary } & $1-5$ & 0.0586 & 0.0736 & 0.0691 \\
\hline & $6-10$ & 0.0587 & 0.0893 & 0.1065 \\
\hline & $11-15$ & 0.0576 & 0.0776 & 0.125 \\
\hline & $16-20$ & 0.0563 & 0.0565 & 0.0945 \\
\hline & $21-25$ & 0.0616 & 0.0522 & 0.0794 \\
\hline & $26-30$ & 0.0656 & 0.0493 & 0.0743 \\
\hline & $31-40$ & 0.0535 & 0.0459 & 0.0758 \\
\hline \multirow[t]{7}{*}{ Primary completed } & $1-5$ & 0.0496 & 0.0447 & 0.0406 \\
\hline & $6-10$ & 0.0393 & 0.0571 & 0.0571 \\
\hline & $11-15$ & 0.0415 & 0.0526 & 0.0692 \\
\hline & $16-20$ & 0.0373 & 0.0462 & 0.0687 \\
\hline & $21-25$ & 0.0356 & 0.0409 & 0.0638 \\
\hline & $26-30$ & 0.0353 & 0.0368 & 0.0534 \\
\hline & $31-40$ & 0.0332 & 0.0337 & 0.0489 \\
\hline \multirow[t]{7}{*}{ Secondary completed } & $1-5$ & 0.0227 & 0.0234 & 0.0252 \\
\hline & $6-10$ & 0.0302 & 0.0327 & 0.0413 \\
\hline & $11-15$ & 0.0448 & 0.0402 & 0.0457 \\
\hline & $16-20$ & 0.0543 & 0.055 & 0.0451 \\
\hline & $21-25$ & 0.0695 & 0.0632 & 0.0637 \\
\hline & $26-30$ & 0.0987 & 0.0874 & 0.0695 \\
\hline & $31-40$ & 0.1389 & 0.1563 & 0.1123 \\
\hline \multirow[t]{7}{*}{ University completed } & $1-5$ & 0.0719 & 0.0726 & 0.1037 \\
\hline & $6-10$ & 0.0929 & 0.0927 & 0.1063 \\
\hline & $11-15$ & 0.0946 & 0.127 & 0.1085 \\
\hline & $16-20$ & 0.11 & 0.1416 & 0.1271 \\
\hline & $21-25$ & 0.1256 & 0.1654 & 0.1435 \\
\hline & $26-30$ & 0.1417 & 0.1852 & 0.1646 \\
\hline & $31-40$ & 0.1478 & 0.2498 & 0.2113 \\
\hline
\end{tabular}

Migration shares are calculated as the share of immigrants in each skill group, over the total male population, age 15-65 in the labor force. 
Table 4: The labor market effect of immigration on natives employment and income (district level, 1996, 2001, 2007)

\begin{tabular}{|c|c|c|c|c|c|c|c|}
\hline & \multicolumn{3}{|c|}{ EMPLOYMENT } & \multicolumn{4}{|c|}{ INCOME } \\
\hline & $\begin{array}{c}(1) \\
(\mathrm{E}+\mathrm{SE}+\mathrm{Oth}) / \mathrm{LF}\end{array}$ & $\begin{array}{c}(2) \\
\mathrm{E} / \mathrm{LF}\end{array}$ & $\begin{array}{c}(3) \\
\mathrm{SE} / \mathrm{LF}\end{array}$ & $\begin{array}{c}(4) \\
\text { Log total income } \\
(\mathrm{LF})\end{array}$ & $\begin{array}{c}(5) \\
\text { Log tot income } \\
(\mathrm{E}+\mathrm{SE}+\mathrm{Oth})\end{array}$ & $\begin{array}{l}(6) \\
\text { Log tot income } \\
(\mathrm{E})\end{array}$ & $\begin{array}{c}(7) \\
\text { Log tot income } \\
(\mathrm{SE})\end{array}$ \\
\hline Migration share & $\begin{array}{c}0.0255 \\
(0.0434)\end{array}$ & $\begin{array}{c}0.0648 \\
(0.0506)\end{array}$ & $\begin{array}{l}-0.0004 \\
(0.0317)\end{array}$ & $\begin{array}{l}-0.1496 \\
(0.1406)\end{array}$ & $\begin{array}{l}-0.0716 \\
(0.1392)\end{array}$ & $\begin{array}{l}-0.0611 \\
(0.1421)\end{array}$ & $\begin{array}{c}0.1480 \\
(0.4664)\end{array}$ \\
\hline Constant & $\begin{array}{c}0.7264^{* * *} \\
(0.0026)\end{array}$ & $\begin{array}{c}0.5725^{* * *} \\
(0.0028)\end{array}$ & $\begin{array}{c}0.0844^{* * *} \\
(0.0017)\end{array}$ & $\begin{array}{c}9.6146^{* * *} \\
(0.0074)\end{array}$ & $\begin{array}{c}9.6272^{* * *} \\
(0.0074)\end{array}$ & $\begin{array}{c}9.6345^{* * *} \\
(0.0076)\end{array}$ & $\begin{array}{c}9.6677^{* * *} \\
(0.0246)\end{array}$ \\
\hline $\begin{array}{l}\text { Skill, year and district } \\
\text { and any two-way in- } \\
\text { teraction FE }\end{array}$ & Yes & Yes & Yes & Yes & Yes & Yes & Yes \\
\hline R-squared & 0.98 & 0.96 & 0.92 & 0.99 & 0.99 & 0.99 & 0.92 \\
\hline $\mathrm{N}$ & 4681 & 4681 & 4681 & 4671 & 4671 & 4638 & 4239 \\
\hline
\end{tabular}

Standard errors clustered at the skill-district level in parethesis. All regressions are weighted by the labor force population in each skill-district group.

Notes: The estimation sample includes the working age (16-65) male labor force population. $\mathrm{E}=$ employed natives in the cell, SE $=$ self-employed natives in the cell, Oth = natives in the cell employed in other active catogories (unpaid/others), LF $=$ natives in the labor force in the cell. Hence, the dependent variable in column (1) measures the native employment rate; the dependent variable in column (2) measures the shares of native employees in the labor force; the dependent variable in column (3) measures the share of native self-employed in the labor force, and columns (4)-(7) capture average native household income for each of these groups. 
Table 5: The labor market effect of immigration on natives employment and income, IV estimates (district level, 1996, 2001)

\begin{tabular}{|c|c|c|c|c|c|c|c|c|}
\hline & \multicolumn{4}{|c|}{ EMPLOYMENT } & \multicolumn{4}{|c|}{ INCOME } \\
\hline & First stage & $\begin{array}{c}(1) \\
(\mathrm{E}+\mathrm{SE}+\mathrm{Oth}) / \mathrm{LF}\end{array}$ & $\begin{array}{c}(2) \\
\mathrm{E} / \mathrm{LF}\end{array}$ & $\begin{array}{c}(3) \\
\mathrm{SE} / \mathrm{LF}\end{array}$ & $\begin{array}{c}(4) \\
\text { Log total income } \\
(\mathrm{LF})\end{array}$ & $\begin{array}{c}(5) \\
\text { Log tot income } \\
(\mathrm{E}+\mathrm{SE}+\mathrm{Oth})\end{array}$ & $\begin{array}{c}(6) \\
\text { Log tot income } \\
(\mathrm{E})\end{array}$ & $\begin{array}{c}(7) \\
\text { Log tot income } \\
(\mathrm{SE})\end{array}$ \\
\hline Migration share & & $\begin{array}{c}-0.4738^{* *} \\
(0.1843)\end{array}$ & $\begin{array}{c}-0.4632^{* *} \\
(0.2018)\end{array}$ & $\begin{array}{l}-0.0455 \\
(0.0759)\end{array}$ & $\begin{array}{l}-0.8809 \\
(0.5738)\end{array}$ & $\begin{array}{l}-0.7024 \\
(0.5721)\end{array}$ & $\begin{array}{l}-0.4879 \\
(0.5613)\end{array}$ & $\begin{array}{l}-2.6052 \\
(2.6629)\end{array}$ \\
\hline IV & $\begin{array}{c}0.2481^{* * *} \\
(0.0499)\end{array}$ & & & & & & & \\
\hline F-test instrument & 24.695 & & & & & & & \\
\hline p-value & 0.000 & & & & & & & \\
\hline $\begin{array}{l}\text { Skill, year and district } \\
\text { and any two-way in- } \\
\text { teraction FE }\end{array}$ & Yes & Yes & Yes & Yes & Yes & Yes & Yes & Yes \\
\hline $\mathrm{N}$ & 3108 & 3108 & 3108 & 3108 & 3100 & 3100 & 3068 & 2804 \\
\hline
\end{tabular}

Standard errors clustered at the skill-district level in parethesis. All regressions are weighted by the labor force population in each skill-district group. Notes: The estimation sample includes the working age (16-65) male labor force population. $\mathrm{E}=$ employed natives in the cell, $\mathrm{SE}=$ self-employed natives in the cell, Oth = natives in the cell employed in other active catogories (unpaid/others), LF = natives in the labor force in the cell. Hence, the dependent variable in column (1) measures the native employment rate; the dependent variable in column (2) measures the shares of native employees in the labor force; the dependent variable in column (3) measures the share of native self-employed in the labor force, and columns (4)-(7) capture average native household income for each of these groups. 
Table 6: The labor market effect of immigration on natives employment and income by ethnicity, IV estimates years 1996-2007

\begin{tabular}{|c|c|c|c|}
\hline & \multicolumn{3}{|c|}{ EMPLOYMENT: $(\mathrm{E}+\mathrm{SE}+\mathrm{Oth}) / \mathrm{LF}$} \\
\hline \multirow[b]{2}{*}{ Migration share } & White & Black/Coloured & Asian \\
\hline & $\begin{array}{c}-1.5735^{*} \\
(0.9494)\end{array}$ & $\begin{array}{c}-0.5933^{* * *} \\
(0.2130)\end{array}$ & $\begin{array}{c}1.4818 \\
(2.3658)\end{array}$ \\
\hline \multirow{4}{*}{$\begin{array}{l}\text { R-squared } \\
\text { N } \\
\text { Education, experi- } \\
\text { ence, year and any } \\
\text { two-way interaction } \\
\text { FE }\end{array}$} & 0.09 & 0.80 & 0.27 \\
\hline & 2378 & 2966 & 1070 \\
\hline & & INCOME: LF & \\
\hline & White & Black/Coloured & Asian \\
\hline Migration share & $\begin{array}{l}-5.1284 \\
(6.7583)\end{array}$ & $\begin{array}{l}-1.0266 \\
(0.6746)\end{array}$ & $\begin{array}{c}-9.3044 \\
(11.2802)\end{array}$ \\
\hline \multirow{4}{*}{$\begin{array}{l}\text { R-squared } \\
\mathrm{N} \\
\text { Education, experi- } \\
\text { ence, year and any } \\
\text { two-way interaction } \\
\text { FE }\end{array}$} & 0.39 & 0.71 & 0.43 \\
\hline & 2330 & 2954 & 1016 \\
\hline & Yes & Yes & Yes \\
\hline & & First stage & \\
\hline Instrument & $\begin{array}{c}0.2196^{* * *} \\
(0.0544)\end{array}$ & $\begin{array}{c}0.2420^{* * *} \\
(0.0502)\end{array}$ & $\begin{array}{c}0.2268^{* * *} \\
(0.0784)\end{array}$ \\
\hline$F 1^{\text {st }}$ stage & 13.640 & 23.204 & 6.956 \\
\hline R-squared & 0.56 & 0.60 & 0.63 \\
\hline $\mathrm{N}$ & 2378 & 2966 & 1070 \\
\hline
\end{tabular}

Standard errors clustered at the skill-district level in parethesis. All regressions are weighted by the labor force population in each skill-district group.

Notes: The estimation sample includes the working age (16-65) male labor force population. $\mathrm{E}=$ employed natives in the cell, $\mathrm{SE}=$ self-employed natives in the cell, Oth = natives in the cell employed in other active catogories (unpaid/others), LF = natives in the labor force in the cell. Hence, the dependent variable in the first panel measures the native employment rate by race; the dependent variable in the second panel measures average household income of natives in the labor force by race. 
Table 7: The labor market effect of immigration on natives employment and income by level of education, IV estimates (district level, 1996, 2001)

\begin{tabular}{|c|c|c|c|c|}
\hline & \multicolumn{4}{|c|}{ EMPLOYMENT: $(\mathrm{E}+\mathrm{SE}+\mathrm{Oth}) / \mathrm{LF}$} \\
\hline & $\begin{array}{c}\text { Less than primary } \\
\text { education }\end{array}$ & $\begin{array}{l}\text { Less than secondary } \\
\text { education completed }\end{array}$ & $\begin{array}{c}\text { Secondary education } \\
\text { completed }\end{array}$ & $\begin{array}{l}\text { University education and } \\
\text { above }\end{array}$ \\
\hline Migration share & $\begin{array}{c}-0.4585^{* * *} \\
(0.1158)\end{array}$ & $\begin{array}{l}-1.3289 \\
(1.1140)\end{array}$ & $\begin{array}{c}0.4595 \\
(0.4451)\end{array}$ & $\begin{array}{c}-0.2781^{* *} \\
(0.1285)\end{array}$ \\
\hline \multirow{5}{*}{$\begin{array}{l}\text { R-squared } \\
\mathrm{N} \\
\text { Education, experience, } \\
\text { year and any two-way } \\
\text { interaction FE }\end{array}$} & 0.82 & 0.91 & 0.89 & 0.48 \\
\hline & 784 & 784 & 784 & 756 \\
\hline & Yes & Yes & Yes & Yes \\
\hline & \multicolumn{4}{|c|}{ INCOME: LF } \\
\hline & $\begin{array}{l}\text { Less than primary } \\
\text { education }\end{array}$ & $\begin{array}{l}\text { Less than secondary } \\
\text { education completed }\end{array}$ & $\begin{array}{l}\text { Secondary education } \\
\text { completed }\end{array}$ & $\begin{array}{l}\text { University education and } \\
\text { above }\end{array}$ \\
\hline Migration share & $\begin{array}{l}-0.6502 \\
(0.4597)\end{array}$ & $\begin{array}{l}-2.2375 \\
(2.5692)\end{array}$ & $\begin{array}{c}0.8548 \\
(1.6930)\end{array}$ & $\begin{array}{l}-0.8069 \\
(0.5796)\end{array}$ \\
\hline R-squared & 0.80 & 0.84 & 0.85 & 0.84 \\
\hline & 784 & 784 & 784 & 748 \\
\hline \multirow{2}{*}{$\begin{array}{l}\text { Education, experience, } \\
\text { year and any two-way } \\
\text { interaction FE }\end{array}$} & Yes & Yes & Yes & Yes \\
\hline & \multicolumn{4}{|c|}{ First stage } \\
\hline Instrument & $0.3572^{* * *}$ & 0.1526 & $0.3553^{* * *}$ & $0.6543^{* * *}$ \\
\hline$F 1^{s t}$ stage & $\begin{array}{c}(0.0479) \\
55679\end{array}$ & $\begin{array}{c}(0.0969) \\
2480\end{array}$ & $(0.1041)$ & $\begin{array}{c}(0.1436) \\
20735\end{array}$ \\
\hline R-squared & 0.81 & 0.80 & 0.46 & 0.54 \\
\hline $\mathrm{N}$ & 784 & 784 & 784 & 756 \\
\hline
\end{tabular}

Standard errors clustered at the skill-district level in parethesis. All regressions are weighted by the labor force population in each skill-district group.

Notes: The estimation sample includes the working age (16-65) male labor force population. $\mathrm{E}=$ employed natives in the cell, $\mathrm{SE}=$ selfemployed natives in the cell, Oth $=$ natives in the cell employed in other active catogories (unpaid/others), LF $=$ natives in the labor force in the cell. Hence, the dependent variable in the first panel measures the native employment rate by education group; the dependent variable in the second panel measures average household income of natives in the labor force by education group. 
Table 8: The labor market effect of immigration on natives employment and income (national level) years 1996-2007

\begin{tabular}{|c|c|c|c|c|c|c|c|}
\hline & \multicolumn{3}{|c|}{ EMPLOYMENT } & \multicolumn{4}{|c|}{ INCOME } \\
\hline & $\begin{array}{c}(1) \\
(\mathrm{E}+\mathrm{SE}+\mathrm{Oth}) / \mathrm{LF}\end{array}$ & $\begin{array}{c}(2) \\
\mathrm{E} / \mathrm{LF}\end{array}$ & $\begin{array}{c}(3) \\
\mathrm{SE} / \mathrm{LF}\end{array}$ & $\begin{array}{c}(4) \\
\text { Log total income } \\
(\mathrm{LF})\end{array}$ & $\begin{array}{c}(5) \\
\text { Log tot income } \\
(\mathrm{E}+\mathrm{SE}+\mathrm{Oth})\end{array}$ & $\begin{array}{c}(6) \\
\text { Log tot income } \\
(\mathrm{E})\end{array}$ & $\begin{array}{c}(7) \\
\text { Log tot income } \\
(\mathrm{SE})\end{array}$ \\
\hline Migration share & $\begin{array}{c}0.3436 \\
(0.2055)\end{array}$ & $\begin{array}{l}-0.0643 \\
(0.2032)\end{array}$ & $\begin{array}{c}0.4030 * * * \\
(0.1383)\end{array}$ & $\begin{array}{c}-2.5824^{* *} \\
(0.9853)\end{array}$ & $\begin{array}{c}-2.5634^{* *} \\
(0.9536)\end{array}$ & $\begin{array}{c}-2.5547 * * * \\
(0.8523)\end{array}$ & $\begin{array}{l}-2.9809 \\
(2.4239)\end{array}$ \\
\hline Constant & $\begin{array}{c}0.7093^{* * *} \\
(0.0103)\end{array}$ & $\begin{array}{c}0.5774^{* * * *} \\
(0.0101)\end{array}$ & $\begin{array}{c}0.0646^{* * *} \\
(0.0069)\end{array}$ & $\begin{array}{c}9.7361^{* * *} \\
(0.0497)\end{array}$ & $\begin{array}{c}9.7504^{* * *} \\
(0.0478)\end{array}$ & $\begin{array}{c}9.7570^{* * *} \\
(0.0431)\end{array}$ & $\begin{array}{c}9.8197^{* * *} \\
(0.1196)\end{array}$ \\
\hline $\begin{array}{l}\text { Skill, year and district } \\
\text { and any two-way in- } \\
\text { teraction FE }\end{array}$ & Yes & Yes & Yes & Yes & Yes & Yes & Yes \\
\hline R-squared & 1.00 & 1.00 & 0.99 & 1.00 & 1.00 & 1.00 & 1.00 \\
\hline $\mathrm{N}$ & 84 & 84 & 84 & 84 & 84 & 84 & 84 \\
\hline
\end{tabular}

Standard errors clustered at the skill-district level in parethesis. All regressions are weighted by the labor force population in each skill-district group.

Notes: The estimation sample includes the working age (16-65) male labor force population. $\mathrm{E}=$ employed natives in the cell, $\mathrm{SE}=$ self-employed natives in the cell, Oth = natives in the cell employed in other active catogories (unpaid/others), LF $=$ natives in the labor force in the cell. Hence, the dependent variable in column (1) measures the native employment rate; the dependent variable in column (2) measures the shares of native employees in the labor force; the dependent variable in column (3) measures the share of native self-employed in the labor force, and columns (4)-(7) capture average native household income for each of these groups. 
Table 9: The effect of immigration on natives mobility years 19962007

\begin{tabular}{|c|c|c|c|}
\hline & $\begin{array}{l}(1) \\
\mathrm{LF}\end{array}$ & $\begin{array}{c}(2) \\
(\mathrm{E}+\mathrm{SE}+\mathrm{Oth})\end{array}$ & $\begin{array}{l}(3) \\
\mathrm{U}\end{array}$ \\
\hline & \multicolumn{3}{|c|}{ PANEL A: OLS District Level } \\
\hline Migration share & $\begin{array}{c}-0.7917^{* * *} \\
(0.1541)\end{array}$ & $\begin{array}{c}-0.7569 * * * \\
(0.1847)\end{array}$ & $\begin{array}{c}-0.6013^{*} \\
(0.3471)\end{array}$ \\
\hline $\begin{array}{l}\text { Education, experi- } \\
\text { ence, year and any } \\
\text { two-way interaction } \\
\text { FE }\end{array}$ & Yes & Yes & Yes \\
\hline R-squared & 0.99 & 0.99 & 0.98 \\
\hline \multirow[t]{2}{*}{$\mathrm{N}$} & 4683 & 4683 & 4683 \\
\hline & \multicolumn{3}{|c|}{ PANEL B: IV District Level } \\
\hline Migration share & $\begin{array}{c}-5.7238 * * * \\
(1.2543)\end{array}$ & $\begin{array}{c}-6.2934^{* * *} \\
(1.3021)\end{array}$ & $\begin{array}{c}-3.1083^{* * *} \\
(1.1970)\end{array}$ \\
\hline $\begin{array}{l}\text { Education, experi- } \\
\text { ence, year and any } \\
\text { two-way interaction } \\
\text { FE }\end{array}$ & Yes & Yes & Yes \\
\hline R-squared & 0.79 & 0.65 & 0.81 \\
\hline $\mathrm{N}$ & 3112 & 3112 & 3112 \\
\hline
\end{tabular}

Standard errors clustered at the skill-district level in parethesis. All regressions at the district level are weighted by the labor force population in each skill-district group.

Notes: The estimation sample includes the working age (16-65) male labor force population. $\mathrm{E}=$ employed natives in the cell, $\mathrm{SE}=$ self-employed natives in the cell, Oth $=$ natives in the cell employed in other active catogories (unpaid/others), LF = natives in the labor force in the cell. Hence, the dependent variable in column (1) measures the stock of natives in the labor force in each cell; the dependent variable in column (2) measures the stock of active natives in each cell; the dependent variable in column (3) measures the stock of unemployed natives in each cell. 


\section{References}

Aron, J., B. Kahn, and G. Kingdon (Eds.) (2009). South African economic policy after democracy. Oxford: Oxford University Press.

Barone, G., A. D’Ignazio, G. De Blasio, and P. Naticchioni (2016). Mr. Rosssi, Mr. Hu and politics: The role of immigration in shaping natives' voting behavior. Journal of Public Economics 136, 1-16.

Bartel, A. P. (1989). Where do the new U.S. immigrants live? Journal of Labor Economics \%, 371-391.

Bhorat, H., J.-B. Meyer, and C. Mlatsheni (2002). Skilled labor migration from developing countries: Study on South and Southern Africa. International Migration Papers 52.

Borjas, G. J. (2003). The labor demand curve is downward sloping: Reexamining the impact of immigration on the labor market. The Quarterly Journal of Economics 40, 1335-1374.

Borjas, G. J. (2006). Native international migration and the labor market impact of immigration. Journal of Human Resources 41, 221-258.

Bosker, M. and W. Krugell (2008). Regional income evolution in South Africa after Apartheid. Journal of Regional Science 48, 493-523.

Card, D. (2001). Immigrant inflows, native outflows, and the local labor market impacts of higher immigration. Journal of Labor Economics 19, 22-64.

Cortes, P. (2008). The effect of low skilled immigration on US prices: Evidence from CPI data. Journal of Political Economy 116, 381-422.

Cortes, P. and J. Pan (2013). Foreign nurse importation and the supply of native nurses. mimeo, Boston University.

Crush, J. (1999). The discourse and dimension of irregularity in post-Apartheid South Africa. International Migration 37, 125-151.

Crush, J. (2000). Migrations past: An historical overview of cross-border movement in Southern Africa. In D. McDonald (Ed.), On borders: Perspectives on international migration in southern Africa, pp. 12-24. New York: St. Martin's Press.

Crush, J. and V. Williams (2010). Labor mmigration trends and policies in Southern Africa. Policy Brief 23.

Department of Labour (2007). Labour migration and south africa: Towards a fairer deal for migrants in the South African economy. Government Printer. 
Du Plessis, S. and B. Smit (2009). South Arica growth revival after 1994. In J. Aron, B. Kahn, and G. Kingdon (Eds.), South African economic policy after democracy, pp. 28-56. Oxford: Oxford University Press.

Friebel, G., J. Gallego, and M. Mendola (2013). Xenophobic attacks, migration intentions and networks: Evidence from the South of Africa. Journal of Population Economics 26, 555-591.

Giuntella, O. and F. Mazzonna (2015). Do immigrants improve the health of natives? Journal of Health Economics 43, 140-153.

Hatton, T. J. and J. Williamson (2005). What fundamentals drive world migration? In G. Borjas and J. Crisp (Eds.), Poverty, International Migration and Asylulm, pp. 15-38. Hampshire, United Kingdom: Palgrave-MacMillan.

ILO (2002). Women and men in the informal economy: a statistical picture. Geneva.

Landau, L. B. and A. W. K. Segatti (2009). Human development impacts of migration: South Africa case study. Working Paper 2009/05.

Lucas, R. E. B. (2006). Migration and economic development in Africa: A review of evidence. Journal of African Economies 15, 337-395.

McDonald, D. A. (2000). On borders. New York: St. Martin's Press.

Mitaritonna, C., G. Orefice, and G. Peri (2017). Immigrants and firms' outcomes: Evidence from France. European Economic Review. forthcoming.

Munshi, K. (2003). Networks in the modern economy: Mexican migrants in the US labor market. Quarterly Journal of Economics 118, 549-597.

Ottaviano, G. I. and G. Peri (2012). Rethinking the effects of immigration on wages. Journal of the European Economic Association 10.

Peberdy, S. (2001). Imagining immigration: Inclusive identities and exclusive policies in post1994 South Africa. Africa Today 48, 15-32.

Peberdy, S. and J. Crush (1998). Rooted in racism: The origin of the Aliens Contriol Act. In J. Crush (Ed.), Beyond control: Immigration and human rights in a democratic South Africa, pp. 18-36. Cape Town: Idasa.

Phillips, B. (2002). Out of Lagos. In H. Holland and A. Roberts (Eds.), From Jo'Burg to Jozi, Stories about Africa's Infamous City, pp. 203-206. London: Penguin Books.

Ratha, D. and W. Shaw (2007). South-South migration and remittances. World Bank WP 102.

Ross, R. (2008). A Concise History of South Africa (Second ed.). Cambridge: Cambridge University Press. 
Statistics South Africa (2012). Documented immigrants in South Africa. Discussion Document D0351.4. 


\section{A1 Appendix}

Figure A1: Change in the likelihood that a migrant from a given region is of skill level $i$ compared to a native

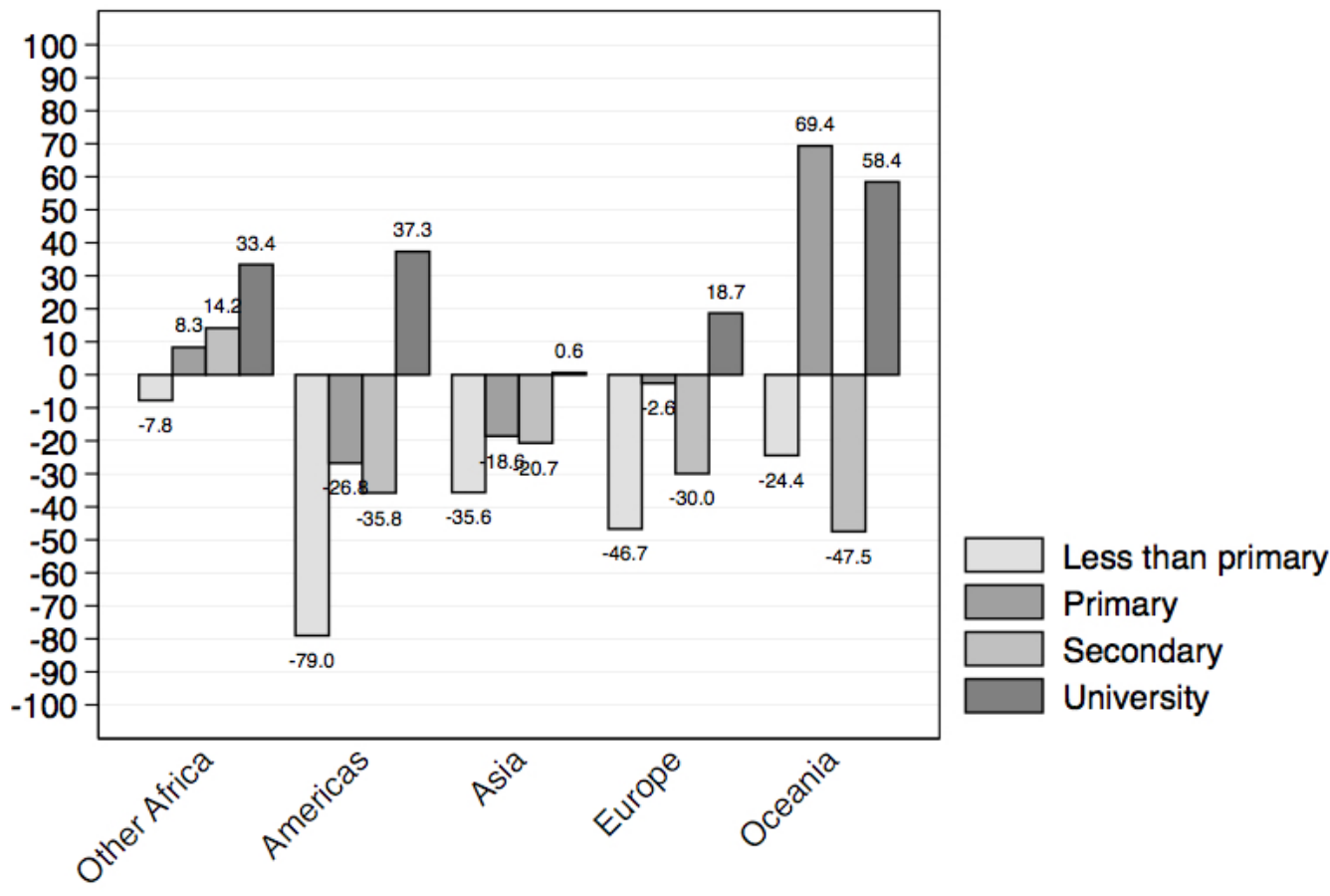

The figure reports the percentage change between 1996 and 2001 of the relative likelihood that a migrant from origin region $j$ will be of skill level $i$ compared to a native, that is letting $R_{j i}=\%$ in education category $i$ from region $j / \%$ in education category $i$ from South Africa, $\left[R_{j i}^{2001}-R_{j i}^{1996}\right] / R_{j i}^{1996} \times 100$.

Table A1: Distribution of income in each income bracket, in 1996, 2001 and 2007

\begin{tabular}{|c|c|c|c|c|}
\hline 1996 Intervals & Distribution in 1996 & 2001-2007 Intervals & Distribution in 2001 & Distribution in 2007 \\
\hline No income & 0.97 & No income & 1.87 & 4.04 \\
\hline $\mathrm{R} 1-2,400$ & 6 & $\mathrm{R} 1-4,800$ & 10.93 & 4.9 \\
\hline $\mathrm{R} 2,401-6,000$ & 13.66 & $\mathrm{R} 4,801-9,600$ & 15.4 & 10.36 \\
\hline $\mathrm{R} 6,001-12,000$ & 19.9 & $\mathrm{R} 9,601-19,200$ & 24.09 & 22.36 \\
\hline $\mathrm{R} 12,001-18,000$ & 20.15 & $\mathrm{R} 19,201-38,400$ & 20.83 & 22.5 \\
\hline $\mathrm{R} 18,001-30,000$ & 14.34 & $\mathrm{R} 38,401-76,800$ & 12.96 & 15.27 \\
\hline R30,001-42,000 & 7.47 & $\mathrm{R} 76,801-153,600$ & 8.01 & 10.47 \\
\hline $\mathrm{R} 42,001-54,000$ & 4.91 & R153,601-307,200 & 3.82 & 5.85 \\
\hline $\mathrm{R} 54,001-72,000$ & 4.67 & R307,201-614,400 & 1.32 & 2.85 \\
\hline R72,001-96,000 & 3.05 & $\mathrm{R} 614,401-1,228,800$ & 0.42 & 0.84 \\
\hline R96,001-132,000 & 2.25 & $\mathrm{R} 1,228,801-2,457,600$ & 0.21 & 0.33 \\
\hline R132,001-192,000 & 1.4 & $\mathrm{R} 2,457,601+$ & 0.14 & 0.24 \\
\hline R192,001-360,000 & 0.88 & & & \\
\hline $\mathrm{R} 360,001+$ & 0.34 & & & \\
\hline
\end{tabular}


Table A2: Summary Statistics: Household salary as a share of Tot. Income (LFS 2001)

\begin{tabular}{lccc}
\hline & Full Sample & Employees & Self-Employed \\
\hline Mean & 0.86 & 0.87 & 0.81 \\
Median & 0.95 & 0.96 & 0.93 \\
$\mathrm{~N}$ & 10353 & 8225 & 1373 \\
\hline
\end{tabular}

Table A3: Correlation between household salary and income (LFS 2001)

\begin{tabular}{lccc}
\hline & \multicolumn{3}{c}{ INCOME } \\
\cline { 2 - 4 } & $(1)$ & $(2)$ & $(3)$ \\
& Full Sample & Employees & Self-Employed \\
\hline Salary & $0.994^{* * *}$ & $0.992^{* * *}$ & $0.994^{* * *}$ \\
Constant & $(0.001)$ & $(0.002)$ & $(0.002)$ \\
& $672.505^{* * *}$ & $649.555^{* * *}$ & $1028.47^{* * *}$ \\
& $(28.938)$ & $(30.060)$ & $(119.042)$ \\
$\mathrm{N}$ & & & 1373 \\
\hline
\end{tabular}

Robust standard errors in parenthesis.

Notes: The data is from the 2001 Labor Force Survey (LFS) and estimates are at the household level. The estimation sample includes all households (col. 1), households with an employee as the main income earner (col.2) and households with a self- employed as main earner (col.3). The dependent variable is monthly household income while the explanatory variable is monthly salary, both from the LFS. Province fixed effects are included as additional controls. 
Table A4: Correlation between household salary and income at the skill/province level (IPUMS-LFS 2001, 2007)

\begin{tabular}{lccc}
\hline & \multicolumn{3}{c}{ INCOME } \\
\cline { 2 - 4 } & $(1)$ & $(2)$ & $(3)$ \\
& Full Sample & Employees & Self-Employed \\
\hline Salary & $0.741^{* * *}$ & $0.934^{* * *}$ & $0.266^{* * *}$ \\
Constant & $(0.023)$ & $(0.033)$ & $(0.020)$ \\
& $17009.170^{* * *}$ & $7401.924^{* * *}$ & $45822.73^{* * *}$ \\
& $(4467.613)$ & $(5954.408)$ & $(6272.168)$ \\
$\mathrm{N}$ & & & 396 \\
\hline
\end{tabular}

Robust standard errors in parenthesis.

Notes: The data are from the 2001, 2007 Labor Force Survey (LFS) and IPUMS and estimates are at the skill/province level. The estimation sample includes all households (col. 1), househols with an employee as the main income earner (col.2) and households with a self-employed as main earner (col.3). The dependent variable is annual household income from IPUMS while the explanatory variable is annual salary from the LFS. Province fixed effects are included as additional controls.

Table A5: Percentage of individuals in each education group, by nativity $(1996,2001,2007)$

\begin{tabular}{|c|c|c|c|c|c|c|}
\hline & \multicolumn{2}{|c|}{1996} & \multicolumn{2}{|c|}{2001} & \multicolumn{2}{|c|}{2007} \\
\hline & Natives & Migrants & Natives & Migrants & Natives & Migrants \\
\hline Less than Primary & 27.08 & 32.67 & 23.51 & 25.96 & 15.8 & 21.08 \\
\hline Less than Secondary & 47.05 & 38.01 & 43.17 & 37.43 & 42.4 & 39.27 \\
\hline Secondary completed (and some college) & 23.44 & 23.49 & 30.02 & 26.73 & 36.89 & 27.86 \\
\hline College completed & 2.43 & 5.82 & 3.3 & 9.88 & 4.92 & 11.79 \\
\hline
\end{tabular}

Notes: The estimation sample includes the working age (16-65) male labor force population. 
Table A6: The labor market effect of immigration on natives employment and income, IV estimates, escluding districts at the border (district level, 1996, 2001)

\begin{tabular}{|c|c|c|c|c|c|c|c|c|}
\hline & \multicolumn{4}{|c|}{ EMPLOYMENT } & \multicolumn{4}{|c|}{ INCOME } \\
\hline & First stage & $\begin{array}{c}(1) \\
(\mathrm{E}+\mathrm{SE}+\mathrm{Oth}) / \mathrm{LF}\end{array}$ & $\begin{array}{c}(2) \\
\mathrm{E} / \mathrm{LF}\end{array}$ & $\begin{array}{c}(3) \\
\mathrm{SE} / \mathrm{LF}\end{array}$ & $\begin{array}{l}(4) \\
\text { Log total income } \\
(\mathrm{LF})\end{array}$ & $\begin{array}{c}(5) \\
\text { Log tot income } \\
(\mathrm{E}+\mathrm{SE}+\mathrm{Oth})\end{array}$ & $\begin{array}{c}(6) \\
\text { Log tot income } \\
(\mathrm{E})\end{array}$ & $\begin{array}{c}(7) \\
\text { Log tot income } \\
(\mathrm{SE})\end{array}$ \\
\hline Migration share & & $\begin{array}{c}-0.4160^{* *} \\
(0.1960)\end{array}$ & $\begin{array}{c}-0.4506^{* *} \\
(0.2123)\end{array}$ & $\begin{array}{l}-0.0061 \\
(0.0837)\end{array}$ & $\begin{array}{l}-0.3741 \\
(0.5503)\end{array}$ & $\begin{array}{l}-0.2400 \\
(0.5540)\end{array}$ & $\begin{array}{l}-0.1645 \\
(0.5493)\end{array}$ & $\begin{array}{c}0.0854 \\
(2.6831)\end{array}$ \\
\hline IV & $\begin{array}{c}0.2916^{* * *} \\
(0.0555)\end{array}$ & & & & & & & \\
\hline F-test instrument & 27.653 & & & & & & & \\
\hline p-value & 0.000 & & & & & & & \\
\hline $\begin{array}{l}\text { Skill, year and district } \\
\text { and any two-way in- } \\
\text { teraction FE }\end{array}$ & Yes & Yes & Yes & Yes & Yes & Yes & Yes & Yes \\
\hline $\mathrm{N}$ & 1948 & 1948 & 1948 & 1948 & 1944 & 1944 & 1930 & 1784 \\
\hline
\end{tabular}

Standard errors clustered at the skill-district level in parethesis. All regressions are weighted by the labor force population in each skill-district group. Notes: The estimation sample includes the working age (16-65) male labor force population. $\mathrm{E}=$ employed natives in the cell, $\mathrm{SE}=$ self-employed natives in the cell, Oth $=$ natives in the cell employed in other active catogories (unpaid/others), LF = natives in the labor force in the cell. Hence, the dependent variable in column (1) measures the native employment rate; the dependent variable in column (2) measures the shares of native employees in the labor force; the dependent variable in column (3) measures the share of native self-employed in the labor force, and columns (4)-(7) capture average native household income for each of these groups. 